\title{
POLEMIKE
}

\section{(NE)OMEJENE MOŽNOSTI GEOGRAFIJE NA PROJEKTNEM TRGU?!}

\author{
AVTORICA \\ dr. Mimi Urbanc \\ Znanstvenoraziskovalni center Slovenske akademije znanosti in umetnosti, Novi trg 2, SI - 1000 Ljubljana, \\ Slovenija \\ mimi.urbanc@zrc-sazu.si
}

DOI: $10.3986 / G V 89204$

UDK: 910:001.89(497.4)

COBISS: 1.02

\section{IZVLEČEK}

(Ne)omejene možnosti geografije na projektnem trgu?!

Namen tega prispevka je podati refleksijo o aktualnem dogajanju in položaju geografije v kontekstu sodobnega kompetitivnega financiranja znanosti. Sprašujem se, kako se geografija kot kompleksno in interdisciplinarno področje umešča v slovenski ter širše evropski sistem znanosti in kako $v$ njem deluje s posebnim ozirom na projektno financiranje. Vsak raziskovalec zna na to vprašanje odgovoriti intuitivno, v prispevku pa poskušam svoja razmišljanja o položaju geografije - sicer brez ambicije po sistematičnosti in celostnosti podkrepiti z nekaterimi podatki. Naslanjam se na prosto dostopne podatke Javne agencije za raziskovalno dejavnost Republike Slovenije in informacijskega sistema SICRIS. V želji po konkretnosti mestoma izpostavljam raziskovalno skupino Geografskega inštituta Antona Melika Znanstvenoraziskovalnega centra Slovenske akademije znanosti in umetnosti. Sklepni ugotovitvi sta, da so možnosti za geografijo zaradi njene interdisciplinarne narave številne ter da evropski projekti niso pomembni le v finančnem smislu, temveč tudi $z$ vidika mreženja in internacionalizacije znanosti.

\section{KLJUČNE BESEDE}

geografija, položaj znanosti, javni sektor, financiranje znanosti, raziskovalna politika, raziskovalne ustanove, raziskovalna agenda, interdisciplinarnost geografije, bibliometrija

\section{ABSTRACT}

\section{(Un)limited opportunities for geography on the project market}

This article offers a reflection on geography's current activity and position in the context of today's competitive funding of research. It asks how geography, as a complex and interdisciplinary field, fits into the Slovenian and broader European research system, and how it operates in this system with special attention to project funding. Every researcher knows how to respond to this question intuitively, and this article supports the author's thoughts on geography's position with certain information, without striving for systematicity or comprehensiveness. It relies on freely available information from the Slovenian Research Agency and the SICRIS information system. In an effort to provide a concrete example, the article highlights the research group at the Anton Melik Geographical Institute of Research Centre of the Slovenian Academy of Sciences and Arts. The concluding findings are that there are many opportunities for geography because of its interdisciplinary nature, and that EU projects are important not only in the financial sense but also from the perspective of networking and the internationalization of research. 


\section{KEY WORDS}

geography, position of sciences, public sector, research funding, research policy, research performing institutions, research agenda, interdisciplinarity of geography, bibliometrics

Uredništvo je prispevek prejelo 30. novembra 2017. 


\section{Uvod}

Geografija je kompleksna, eklektična in aplikativna veda, kar napeljuje na misel, da bi morala biti v sodobni družbi in politiki, ki ju zaznamuje želja po preseganju meja disciplin, sodelovanju in iskanju relevantnosti ter uporabnosti, visoko cenjena. Posledično torej geografija v sistemu znanosti ne bi smela imeti eksistencialnih težav. Pa je res tako? Odgovor na to vprašanje zahteva tehten premislek, $\mathrm{h}$ kateremu prispeva ta članek. Prav je, da se akterji in deležniki vsakega področja občasno ozrejo vase, v svoje delo in okvir, znotraj katerega delujejo.

Prispevek pred vami je moj osebni pogled na dogajanje v geografiji. Nastal je kot nadaljevanje in nadgradnja predavanja na Zborovanju slovenskih geografov septembra 2017 v Mariboru, kjer sem na povabilo organizatorjev predstavila isto problematiko. Izhajam iz dolgoletnih raziskovalnih izkušenj, ki jih že osmo leto plemenitim z izkušnjami iz upravljanja znanosti. Osebni pogled mestoma podkrepim $\mathrm{z}$ ugotovitvami iz literature in podatki iz javno dostopnih podatkov Javne agencije za raziskovalno dejavnost Republike Slovenije (v nadaljevanju ARRS), informacijskega sistema SICRIS in - zgolj v želji po večji konkretnosti - institucionalnimi podatki o raziskovalni skupini Geografskega inštituta Antona Melika Znanstvenoraziskovalnega centra Slovenske akademije znanosti in umetnosti (GIAM ZRC SAZU; Perko in Zorn 2016). Cilj prispevka je prispevati k razumevanju položaja geografije v javnih raziskovalnih zavodih in sistemu znanosti nasploh. Sprašujem se, kako se geografija kot kompleksno in interdisciplinarno področje umešča v slovenski ter širše evropski sistem znanosti in kako v njem deluje s posebnim ozirom na projektno financiranje.

Skladno s terminologijo ARRS uporabljam izraz veda za humanistiko, družboslovje, naravoslovje in tako naprej ter izraz področje oziroma polje za geografijo, zgodovinopisje in tako naprej. Družboslovje in humanistika pogosto nastopata skupaj, zato ju v nadaljevanju imenujem z uveljavljeno mednarodno kratico SSH, ki označuje Social Sciences and Humanities. Zaradi pragmatičnosti uporabljam samo moško obliko oznake za raziskovalko oziroma raziskovalca in geografinjo oziroma geografa.

\section{Položaj in financiranje geografije v Sloveniji}

Položaj geografije v slovenskem sistemu znanosti in družbi nasploh bi si zaslužil celovito tematizacijo, kar pa je zunaj obsega tega prispevka. Dotaknila se bom le nekaterih vidikov. Bistvo geografije njena interdisciplinarna narava - je hkrati prednost in težava. Če bi bila geografija oseba, bi zanjo rekli, da je razcepljena osebnost oziroma da ima - s sodobnejšim izrazom - disociativno motnjo identitete. Geografijo in njena podpodročja namreč različne klasifikacije, kakor je razvidno iz slike 1, umeščajo $\mathrm{v}$ različne vede. V ARRS strukturi znanstvenih področij geografija sodi v humanistiko. Tudi študij geografije v Sloveniji poteka na humanističnih fakultetah. Nacionalne agencije in izobraževalni sistemi drugih držav geografijo umeščajo zelo različno in po nekje - zlasti anglosaksonskem svetu - se zaradi institucionalnega razvoja ter reorganizacije staplja $\mathrm{v}$ interdisciplinarna področja in oddelke (Hall in sodelavci 2015; Wainwright 2015). Pregled položaja geografije v akademski institucionalni organiziranosti podaja Banski $(2012 ; 2013)$.

Položaj raziskovalcev, pri čemer imam $\mathrm{v}$ mislih raziskovalce $\mathrm{z}$ javnih raziskovalnih zavodov ( $\mathrm{v}$ nadaljevanju JRZ), določa pravno-formalni okvir javnega sektorja. Raziskovalna dejavnost sodi v resor Ministrstva za izobraževanje, znanost in šport (v nadaljevanju MIZŠ). Raziskovalci so javni uslužbenci, vendar nimajo sistematiziranih delovnih mest, kar povzroča vrsto izzivov, obenem pa njihovo število in struktura nista opredeljeni. ARRS je organ, ki izvaja strokovne, razvojne in izvršilne naloge v zvezi s politikami MIZŠ-ja oziroma nacionalnim raziskovalnim in razvojnim programom. Vsebinske usmeritve vsake raziskovalne skupine opredeljuje raziskovalni program ARRS-ja, ki je večinoma šestletni in razmeroma stabilen. Glavnina trenutno potekajočih programov ne pokrije mnogo več od minimalnih potreb določene stroke. Programe ARRS-ja dopolnjujejo projekti oziroma sredstva, ki jih ARRS razdeli prek 


\section{CERIF KLASIFIKACIJA}

\section{DRUŽBOSLOVJE S 000}

S 230 Družbena geografija

\section{NARAVOSLOVNO-MATEMATIČNE VEDE P 000}

Geologija, fizična geografija P 005

P 470 Hidrogeologija, inženirska geografija in inženirska geologija

P 510 Fizična geografija, geomorfologija, pedologija, kartografija, klimatologija

\section{BIOMEDICINSKE VEDE B 000}

Botanika B 004

B 290 Sistematična botanika, sistematika, morfologija, fitogeografija, kemotaksonomija

Zoologija B 005

B 320 Sistematična zoologija, sistematika, zoogeografija

\section{HUMANISTIČNE VEDE H 000}

Zgodovina in umetnost 003

H 280 Lokalna in regijska zgodovina, zgodovinska geografija od srednjega veka naprej
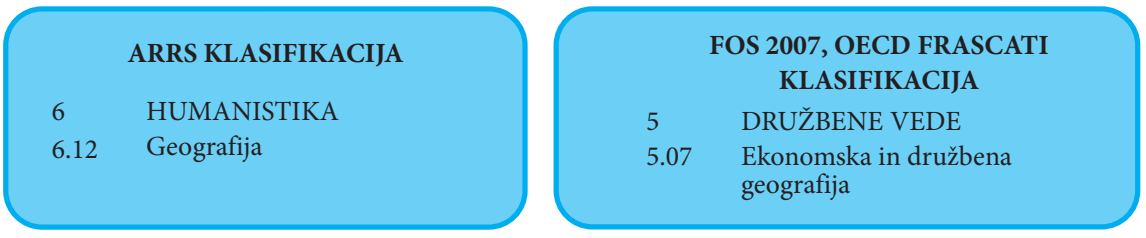

Slika 1: Umestitve geografije v sistem znanosti.

razpisov in zelo variirajo od leta do leta. Sredstva iz EU programov, ki jih analiziram v poglavju 7 in 8 , so še bolj nepredvidljiva. Tržna sredstva pa so, kot kaže primer raziskovalne skupine GIAM (slika 2), $\mathrm{v}$ zadnjem desetletju in pol v finančnem smislu postala nepomembna. Sredstva ARRS so nujna za uravnavanje nihanj v financiranju, saj kljub togim nacionalnim in ARRS predpisom odpirajo - sicer majhen manevrski prostor za nemoteno poslovanje. Razmejevanje ARRS prihodkov med leti omogoča, da sredstva, ki prihajajo v enakomernih deležih uskladimo $\mathrm{z}$ dinamiko dela na projektih in programu. Financiranje raziskav je enačba $z$ veliko neznankami, od katerih pa so odvisni raziskovalci, ki s projekti pridobivajo sredstva za svoje (osnovne in edine) plače.

Stabilna in zadostna sredstva so nujna za dolgoročen razvoj znanosti in tudi za vključevanje raziskovalnih skupin v konzorcije evropskih (EU) projektov, zato trenutni način financiranja znanosti ni spodbuden in bi zahteval temeljito prenovo. Skrb zbujajo predvsem majhen obseg sredstev v programih, nepredvidljiva dinamika vsakokratnega razpisa in obseg sredstev za posamezno področje, določen na osnovi nerazumljive politike izpred dveh desetletij ter omajano zaupanje raziskovalcev v transparentnost in strokovnost izbirnih postopkov. Okvir celotnemu sistemu postavljajo pretekle prakse in dogovori, znotraj katerega pa se raziskovalno delo vrednoti in financira po principu meritokracije.

$\mathrm{Na}$ uspeh na projektnih razpisih in s tem dejansko vključenost raziskovalne skupine v domači in evropski znanstveni sistem vplivajo različni notranji in zunanji dejavniki. K notranjim dejavnikom prištevamo kakovost raziskovalnega dela, vidnost in prepoznavnost raziskovalcev ter njihove stike (osebne in institucionalne) in mobilnost. K zunanjim dejavnikom prištevamo znanstvene politike in $\mathrm{z}$ njimi 


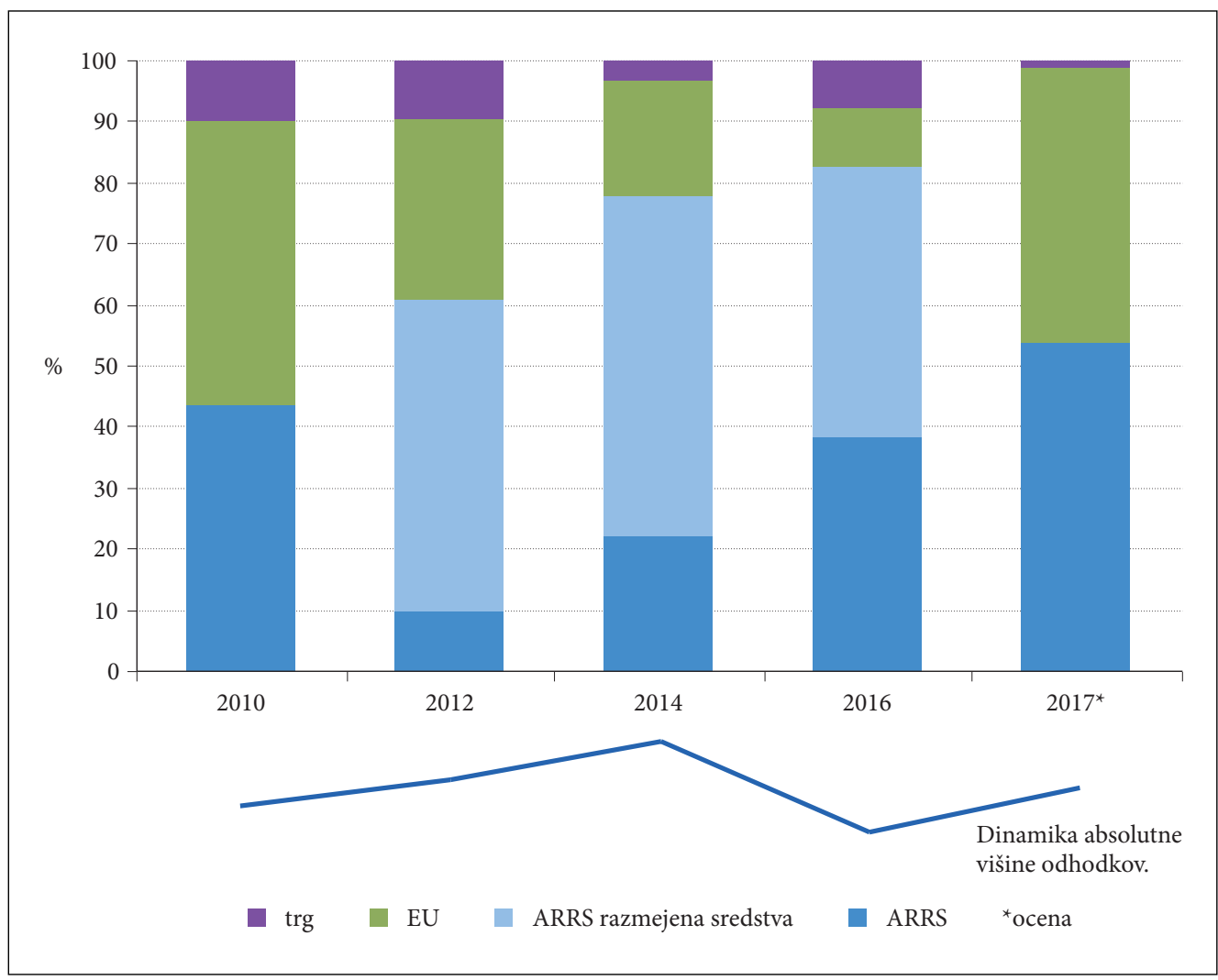

Slika 2: Struktura odhodkov raziskovalne skupine GIAM ZRC SAZU po viru in njihova dinamika $\left({ }^{*}\right.$ ocena).

povezan obseg razpoložljivih sredstev in razpisanih tem, nacionalno in mednarodno tekmovalno okolje ter položaj geografije v znanosti in družbi.

\section{Kakovost geografskega raziskovalnega dela}

Kakovost raziskovalnega dela je zelo kompleksno vprašanje. Tu podajam le nekaj osnovnih informacij, ki okvirno osvetljujejo ta vidik. Pri tem moram jasno poudariti, da bibliografska metrika (pretvorba bibliografskih podatkov v številke) razkriva zgolj enega od vidikov kakovosti ter jo je treba presojati in razumeti v širšem kontekstu. Znotraj SSH skupnosti je veliko dvomov in polemik o njeni (ne)ustreznosti. Vrednotenje SSH je predmet samostojnih projektov, kot je na primer ENRESSH (medmrežje 1). Bibliometrija je uporaben in dober, ne pa edini in vseobsegajoč pokazatelj in bi jo veljalo vsake toliko analizirati, kot je to naredil Perko (2010). Znotraj slovenske znanosti se po kazalniku citiranosti geografske raziskovalne skupine odlično uvrščajo. Slika 3 kaže, kako se raziskovalne skupine, ki jih ARRS beleži kot geografske, umeščajo med zgornjih 20 skupin v humanistiki (od skupno 1403 raziskovalnih skupin).

Tudi kot posamezniki se geografi visoko uvrščamo na lestvici prvih sto raziskovalcev glede na posamični kazalnik (preglednica 1), vendar najvišje le po kriteriju citiranosti. Geografija tu s pridom izkorišča svojo interdisciplinarno naravo. 


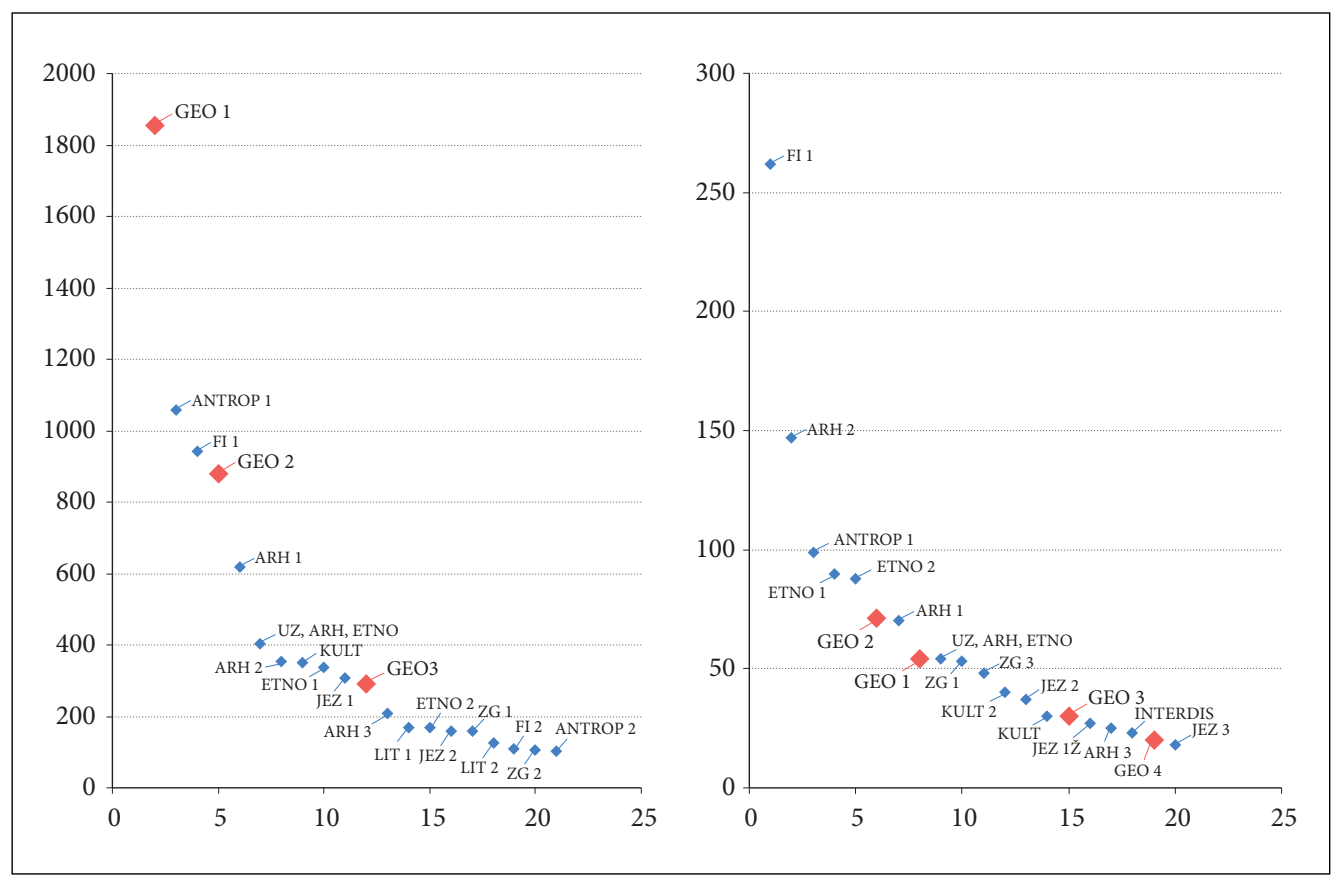

Slika 3: Razvrstitev prvih dvajset raziskovalnih skupin v humanistiki glede na kazalnika CI10 (levo) in CImax (desno) (CI10 je število čistih citatov znanstvenih del (objavljenih kadarkoli) v zadnjih 10 letih; CImax je najodmevnejše delo $v$ zadnjih 10 letih; raziskovalne skupine so poimenovane zgolj s področjem; vir: SICRIS, 16. 9. 2017).

Preglednica 1: Najvišje uvrščeni geografi glede na izbrane kazalnike ARRS-ja (A1 so vse objave; A" so izjemni dosežki, torej objave v najboljših svetovnih publikacijah; CI10 je število čistih citatov znanstvenih del (objavljenih kadarkoli) v zadnjih 10 letih; CImax je najodmevnejše delo v zadnjih 10 letih; A3 so sredstva zunaj ARRS; vir: SICRIS, 16. 9.2017).

kazalnik geograf najvišje na seznamu število geografov na seznamu (od 100)

$\begin{array}{lrr}\text { A1 } & \text { 45. mesto } & 5 \\ \text { A" } & 62 . \text { mesto } & 3 \\ \text { CI10 } & 4 . \text { mesto } & 35 \\ \text { CImax } & \text { 8. mesto } & 28 \\ \text { A3 } & 12 . \text { mesto } & 21\end{array}$

Rahlo drugačna je podoba, ko geografske raziskovalne skupine pogledamo v luči objav (preglednica 2). Primerjam štiri (glede na ARRS klasifikacijo geografske) raziskovalne skupine (dve z JRZ, dve z univerz), ki veliko objavljajo, vendar je med objavami le malo takšnih, ki po kriterijih ARRS-ja sodijo med izjemne dosežke (Pravilnik o ... 2016). To so objave v najboljših revijah, torej v 1. četrtini revij po kazalniku SNIP za SSH in v zgornjih $10 \%$ (približno $40 \% 1$. četrtine) revij s področja naravoslovja in tehnike. 
Preglednica 2: Objave geografskih raziskovalnih skupin v najvišje uvrščenih revijah in monografijah svetovno priznanih založb od 2007 do 2017 ( ${ }^{*}$ skupine imajo enako zaporedno številko kot na sliki 3, ${ }^{* *}$ metodologija ARRS: znanstveni članki 1.01, 1.02, 1.03, +metodologija ARRS: prvi kvartal revij, ki so uvrščene $v$ SSH ter približno $40 \%$ prvega kvartala revij, uvrščenih v naravoslovje, medicino in tehniko; ++ pri revijah, uvrščenih v SSH se A" in prvi kvartal 1 A1 ujemata, pri revijah uvrščenih v naravoslovje, medicino in tehniko, je približno prvih $40 \%$ 1. kvartala tudi A"; \#samo monografije, izdane pri najboljših svetovnih založbah so A", slovenske založbe niso na seznamu, šteje samo monografija kot celota, ne posamezno poglavje; 1 avtor pomeni, da je član te raziskovalne skupine prvi ali edini avtor; vir: SICRIS, 22. 11. 2017).

\begin{tabular}{|c|c|c|c|c|c|c|c|c|}
\hline \multirow[t]{2}{*}{ skupina* $^{*}$} & \multirow[t]{2}{*}{ obdobje } & \multicolumn{7}{|c|}{ število } \\
\hline & & $\begin{array}{c}\text { vseh } \\
\text { člankov }\end{array}$ & $\begin{array}{l}\text { vseh A" } \\
\text { člankov+ }\end{array}$ & $\begin{array}{c}\text { A" člankov } \\
\text { iz tujih } \\
\text { revij }\end{array}$ & $\begin{array}{c}\text { vseh } \\
\text { člankov } \\
\text { 1. kvartala } \\
(1 \mathrm{~A} 1)++\end{array}$ & $\begin{array}{l}\text { člankov } \\
\text { 1. kvartala } \\
\text { iz tujih } \\
\text { revij }\end{array}$ & $\begin{array}{c}\text { vseh } \\
\text { mono- } \\
\text { grafij }^{* * *}\end{array}$ & $\begin{array}{c}\text { A" mono- } \\
\text { grafij\# }\end{array}$ \\
\hline
\end{tabular}

\begin{tabular}{lcccccccc}
\hline GEO 1 & $2006-2011$ & 144 & 9 & 2 & 9 & 2 & 27 & $/$ \\
\hline GEO 1 & $2012-2017$ & 173 & 13 & $\begin{array}{c}2(1 \text { prvi } \\
\text { avtor })\end{array}$ & 21 & $\begin{array}{c}9(5 \text { prvi } \\
\text { avtor })\end{array}$ & 23 & $/$ \\
\hline GEO 2 & $2006-2011$ & 119 & 2 & 1 & 16 & $\begin{array}{c}15(8 \text { prvi } \\
\text { avtor })\end{array}$ & 4 & 1 \\
\hline GEO 2 & $2012-2017$ & 111 & 4 & $\begin{array}{c}4(3 \text { prvi } \\
\text { avtor })\end{array}$ & 23 & $\begin{array}{c}23(15 \text { prvi } \\
\text { avtor })\end{array}$ & 9 & $\begin{array}{c}4(3 \text { prvi } \\
\text { avtor })\end{array}$ \\
\hline GEO 3 & $2006-2011$ & 96 & 2 & $\begin{array}{c}1 \text { (prvi } \\
\text { avtor })\end{array}$ & 3 & $\begin{array}{c}2 \text { (1 prvi } \\
\text { avtor })\end{array}$ & 13 & $/$ \\
\hline GEO 3 & $2012-2017$ & 96 & 1 & 1 & 3 & 3 & 15 & $/$ \\
\hline GEO 4 & $2012-2017$ & 70 & 1 & 1 & 1 & 1 & 12 & $/$ \\
\hline GEO 4 & $2006-2011$ & 83 & $/$ & $/$ & $/$ & $/$ & 6 & $/$ \\
\hline
\end{tabular}

Dodatno kakovost geografije pokaže uvrstitev slovenskih geografskih revij (preglednica 3) glede na kazalnik SNIP, ki ga ARRS upošteva pri razvrščanju revij s področja SSH v četrtine. Pri Acti Carsologici se uporablja kazalnik JCR, ki ga ARRS upošteva pri razvrščanju revij s področja naravoslovja in tehnike v četrtine. Četrtina 1 pomeni, da je revija v zgornji četrtini, kjer so najboljše revije, četrtina 4 pa zadnjo četrtino revij glede na kazalnik (SNIP ali JCR). Geografske revije so v zadnjem desetletju napravile velik korak že z uvrstitvijo v ustrezne indekse. Na področju prepoznavnosti in kakovosti pa je še prostor za izboljšavo.

Preglednica 3: Uvrstitev slovenskih revij s področja geografije (vir: COBISS, 16. 9. 2017).

\begin{tabular}{lccccc}
\hline \multicolumn{1}{c}{ SNIP (četrtina) } & SNIP 2005 & SNIP 2010 & SNIP 2014 & SNIP 2015 & SNIP 2016 \\
REVIJA & & & & & \\
\hline Acta geographica Slovenica & 4 & 4 & 1 & 3 & 1 \\
Acta Carsologica (JCR) & $/$ & 4 & 4 & 4 & 4 \\
Dela & $/$ & 3 & 3 & 4 & 4 \\
Geografski vestnik & 3 & 4 & 4 & 4 & 4 \\
Revija za geografijo & $/$ & $/$ & $/$ & $/$ & $/$ \\
\hline
\end{tabular}


Bibliometrija včasih bolj, včasih manj vpliva na življenje raziskovalcev, še zlasti v povezavi z ARRS viri financiranja. Že več kot desetletje pri raziskovalcih generira frustracije in nemoč, predvsem zaradi stalne spremenljivosti in nepredvidljivosti. Izbirni postopek pri nekaterih razpisih, na primer za dodelitev mentorskih mest za mlade raziskovalce, so v celoti sloneli na njej. V zadnjih letih se je njena vsemogočnost sicer razrahljala, kljub vsemu pa ni povsem izzvenela. Še vedno je odločujoča pri nekaterih razpisih za manjše projekte, na primer bilateralne, ki financirajo zgolj materialne stroške obiskov. Pri temeljnih in aplikativnih projektih ARRS-ja pa nastopa zgolj kot vstopni pogoj.

Bibliometrija sloni na komercialnih informacijskih virih, ki prinašajo kategorizacijo revij glede na kakovost, tako imenovanih indeksih citiranosti in že omenjene razvrstitve v četrtine, ki iz njih izhajajo. Indeksi citiranosti so sicer povsem ustrezen kazalnik kakovosti revije (čeprav ne edini), težava pa je v njihovem spreminjanju za nazaj. Vsakič, ko se indeksa SNIP in JCR, ki ju ARRS in IZUM uporabljata pri računanju znanstvene odličnosti, spremenita za tekoče oziroma predhodno leto, se spremenita tudi za leta nazaj. Ko je 1. septembra 2017 Inštitut informacijskih znanosti v Mariboru (IZUM) namestil novo bazo SNIP 1999-2016, se je lahko spremenila uvrstitev posamične revije in posledično točke, ki jih članek v reviji prinaša, za skoraj 20 let nazaj. Naj ponazorim na primeru mojega članka, objavljenega leta 2008 (Urbanc 2008) v Geografskem vestniku (preglednica 4).

Preglednica 4: Spreminjanje kategorizacije in števila točk članka, objavljenega leta 2008 v Geografskem vestniku (vir: SICRIS $z$ dne, kot kaže prvi stolpec; razlaga kategorij izhaja iz Pravilnika o ... 2016).

datum kategorija objave (ARRS) število točk

\begin{tabular}{rcr}
4.10 .2011 & $1 \mathrm{C}(\mathrm{Z} 1)$ & 30,00 \\
2.10 .2013 & $\mathrm{CC}(\mathrm{Z} 1)$ & 30,00 \\
15.9 .2014 & $1 \mathrm{~A} 2\left(\mathrm{Z} 1, \mathrm{~A}^{\prime}, \mathrm{A} 1 / 2\right)$ & 92,78 \\
5.10 .2015 & $1 \mathrm{~A} 1\left(\mathrm{Z}, \mathrm{A}^{\prime}, \mathrm{A} 1 / 2\right)$ & 110,70 \\
16.8 .2016 & $1 \mathrm{~A} 1\left(\mathrm{Z}, \mathrm{A}^{\prime}, \mathrm{A} 1 / 2\right)$ & 110,70 \\
27.6 .2017 & $1 \mathrm{~A} 1\left(\mathrm{Z}, \mathrm{A}^{\prime}, \mathrm{A}^{\prime}, \mathrm{A} 1 / 2\right)$ & 110,70 \\
2.11 .2017 & $1 \mathrm{~A} 3\left(\mathrm{Z}, \mathrm{A}^{\prime}, \mathrm{A} 1 / 2\right)$ & 73,42 \\
\hline
\end{tabular}

\section{Mobilnost geografov}

Za kakovostno raziskovalno delo je ključnega pomena mobilnost, saj prispeva tako k pridobivanju novega znanja kot njegovem prenosu. Pomena mobilnosti v 21. stoletju ni treba več posebej dokazovati, saj ga kot temeljni kamen evropskega raziskovalnega prostora izpostavlja celotna raziskovalna politika EU-ja. Želja po mobilnosti je šla tako daleč, da obstaja vrsta programov, kjer mobilnost ni le instrument za dosego ciljev, ampak cilj sam (Erasmus, COST, Marie Skladowska Curie; med slovenskimi pa bilateralni projekti ARRS-ja).

Slovenski geografski raziskovalni prostor zaznamuje skoraj popolna zaposlitvena nemobilnost. V nasprotju z evropskim in svetovnim raziskovalnim prostorom, kjer se zaposlitvena mobilnost raziskovalcev začne šele po končanem študiju (Bauder 2015), v slovenskih geografskih ustanovah mobilnosti po pridobitvi doktorskega naziva skoraj ni. Zaposlitveni trg akademske delovne sile deluje samo z vidika biti in ostati v akademskem okolju (preglednica 6), znotraj njega pa je zaposlitvena mobilnost izjemno majhna (preglednica 5).

Trditev, da mobilnost deluje samo z vidika vstopa ali izstopa iz raziskovalnega prostora, potrjuje tudi preglednica mobilnosti in zaposlitev mladih raziskovalcev (MR). Ko je pred dobrimi tremi desetletji nastal inštrument usposabljanja MR-jev, je bil njegov namen obnova raziskovalnega potenciala na 
Preglednica 5: Zaposlitvena (ne)mobilnost geografov (vir: SICRIS, 16. 9. 2017).

\begin{tabular}{lccc}
\hline raziskovalna skupina & $\begin{array}{c}\text { število zaposlenih } \\
\text { (brez mladih raziskovalcev } \\
\text { in tehnikov) }\end{array}$ & $\begin{array}{c}\text { število zaposlenih } \\
\text { tujcev }\end{array}$ & $\begin{array}{c}\text { število zaposlenih } \\
\text { z doktoratom tuje } \\
\text { univerze (brez tujcev) }\end{array}$ \\
\hline GEO 1 & 24 & $/$ & 1 \\
GEO 2 & 13 & 1 & 0 \\
GEO 3 & 20 & $/$ & 1 \\
GEO 4 & 8 & $/$ & 1 \\
\hline
\end{tabular}

Preglednica 6: Spol, uspešen zaključek študija, mobilnost in zaposlitev mladih raziskovalcev (†pokojen; M - moški, F- ženska; vir: ARRS, 16. 9. 2017).

\begin{tabular}{|c|c|c|c|c|c|}
\hline leto & spol & doktoriral/a & $\begin{array}{l}\text { akademska } \\
\text { sfera }\end{array}$ & $\begin{array}{c}\text { akademska sfera - } \\
\text { druga ustanova }\end{array}$ & $\begin{array}{c}\text { sektor (če ni } \\
\text { akademska sfera) }\end{array}$ \\
\hline \multirow{2}{*}{2002} & M & $\checkmark$ & $\checkmark$ & & \\
\hline & $\mathrm{M}$ & $\checkmark$ & $\checkmark$ & & \\
\hline \multirow[t]{3}{*}{2004} & M & $\checkmark$ & $\checkmark$ & & \\
\hline & $\mathrm{M}$ & $\checkmark$ & $\checkmark$ & & \\
\hline & $\mathrm{M}$ & $\checkmark$ & & & gospodarstvo \\
\hline \multirow[t]{3}{*}{2005} & $\mathrm{M}$ & $\checkmark$ & & & javna uprava \\
\hline & $\mathrm{F}$ & $\checkmark$ & $\checkmark$ & & \\
\hline & M (geologija) & $\checkmark$ & $\checkmark$ & $\checkmark$ & \\
\hline \multirow[t]{2}{*}{2006} & $\mathrm{~F}$ & $\checkmark$ & $\checkmark$ & & \\
\hline & M & $\checkmark$ & $t$ & & \\
\hline 2007 & $\mathrm{~F}$ & $\checkmark$ & $\checkmark$ & & \\
\hline 2008 & $\mathrm{M}$ & $\checkmark$ & $\checkmark$ & & \\
\hline \multirow[t]{3}{*}{2009} & $\mathrm{~F}$ & $\checkmark$ & & & gospodarstvo \\
\hline & M & $\checkmark$ & $\checkmark$ & & \\
\hline & $\mathrm{F}$ & $\checkmark$ & & & osnovna šola \\
\hline \multirow[t]{2}{*}{2010} & $\mathrm{~F}$ & $\checkmark$ & $\checkmark$ & & \\
\hline & $\mathrm{F}$ & $\checkmark$ & & & gospodarstvo \\
\hline \multirow[t]{3}{*}{2011} & $\mathrm{M}$ & $\checkmark$ & $\checkmark$ & & \\
\hline & $\mathrm{F}$ & & $\checkmark$ & & \\
\hline & $\mathrm{F}$ & & $\checkmark$ & & \\
\hline \multirow[t]{3}{*}{2012} & $\mathrm{~F}$ & $\checkmark$ & $\checkmark$ & $\checkmark$ & \\
\hline & M & $\checkmark$ & $\checkmark$ & & \\
\hline & $\mathrm{M}$ & & & & gospodarstvo \\
\hline
\end{tabular}


univerzah in inštitutih ter pretok v razvojne oddelke oziroma projekte gospodarstva in negospodarstva (Baškovič 2016). Vidik pretoka je zlasti v SSH v veliki meri izzvenel. Preglednica 6 kaže, da je med letoma 2002 in 2012 geografija dobila 23 mest za MR-je, pri čemer je bil samo na eno od teh mest izbran negeograf in na eno tujec. Šest MR-jev ni več v akademski sferi in od štirih, ki imajo v preglednici navedeno gospodarsko delovno mesto, za eno osebo vem, da je izstopila prostovoljno in našla nove izzive v visoko tehnološkem podjetju. Brskanje po svetovnem spletu je za druge tri pokazalo, da je njihova oblika zaposlitve s. p., kar verjetno nakazuje na reševanje brezposelnosti, še zlasti ker je skoraj tretjina MR-jev s področja humanistike iz tega obdobja končala med brezposelnimi (več o tem glej Novak 2016). Samo dva izmed $16 \mathrm{MR}$-jev s področja geografije, ki so še vedno v akademskem svetu, začetek septembra 2017 nista bila zaposlena na isti ustanovi, na kateri sta se usposabljala med doktorskim študijem.

Ker so pretok idej, informacij in navezovanje stikov ključnega pomena v sodobnem raziskovalnem svetu, je manko zaposlitvene mobilnosti treba nadomestiti. Glede na podatke iz preglednic 5 in 6 bi sklepali, da so druge poti mobilnosti bolj izrazite. Celovitih podatkov o mobilnosti sodelavcev štirih raziskovalnih skupin nimam, imam pa podatke o raziskovalni skupini GIAM, ki kažejo, da niso mobilni vsi raziskovalci in da $\mathrm{k}$ mobilnosti v veliki meri prispevajo EU projekti. Mobilnost precej niha od leta do leta in je povezana s finančnim stanjem. Obenem preglednica 7 kaže, da je daljše (več kot 1 mesec) raziskovalno delo v tujini prej izjema kot pravilo.

Preglednica 7: Mobilnost raziskovalcev GIAM-a v letih 2006, 2010, 2012, 2014 in 2016 ( ${ }^{*}$ daljši od enega meseca; vir: Poročilo o delu ZRC SAZU 2006, 2010, 2012, 2014 in 2016).

\begin{tabular}{lccccccc}
\hline leto & $\begin{array}{c}\text { število } \\
\text { raziskovalcev } \\
\text { (vključno z MR) }\end{array}$ & $\begin{array}{c}\text { število } \\
\text { mobilnih } \\
\text { raziskovalcev }\end{array}$ & & & & & \\
& & & $\begin{array}{c}\text { oblike mobilnosti } \\
\text { projektni } \\
\text { sestanki }\end{array}$ & $\begin{array}{c}\text { konference, } \\
\text { delavnice in } \\
\text { izobraževanja }\end{array}$ & $\begin{array}{c}\text { članstvo } \\
\text { komisijah, } \\
\text { odborih }\end{array}$ & $\begin{array}{c}\text { priprava } \\
\text { novih } \\
\text { projektov }\end{array}$ & $\begin{array}{c}\text { raziskovalno } \\
\text { delo v tujini } \\
\text { in strokovne } \\
\text { ekskurzije }\end{array}$ \\
\hline 2006 & 20 & 11 & 8 & 4 & 0 & 0 & 6 \\
2010 & 26 & 16 & 20 & 33 & 2 & 3 & 12 \\
2012 & 29 & 22 & 40 & 27 & 2 & 2 & $17+1^{*}$ \\
2014 & 28 & 15 & 13 & 10 & 2 & 1 & $7+4^{*}$ \\
2016 & 28 & 14 & 8 & 9 & 3 & 2 & 9 \\
\hline
\end{tabular}

\section{Interdisciplinarnost geografije}

Poleg prostorske mobilnosti je za pretok idej pomembna tudi interdisciplinarnost, ki je geografiji inherentna (Baerwald 2010). To je sicer njena prednost, vendar v vsakdanjem življenju znanosti lahko povzroča tudi težave (glej sliko 1 zgoraj). Poleg tega je interdisciplinarnost neustrezno naslovljena v nacionalni raziskovalni politiki. Ostro in strogo razmejenost med posameznimi polji delno blaži možnost prijave interdisciplinarnih projektov, ki pa »zajedajo« sredstva sodelujočih polj. Slika 4 kaže prijave na interdisciplinarno polje pri ARRS-ju od 2012 dalje, ko se je ta možnost odprla. Od 15 vlog je bila geografija navedena kot prvo polje pri kar 13 projektih. Iz tega lahko sklepamo, da so večinoma geografi tisti, ki oblikujejo interdisciplinarne predloge. Zaradi zelo omejenih sredstev na interdisciplinarnem polju je možnost uspeha minimalna. Na drugi strani pa je politika Evropske unije interdisciplinarnost 


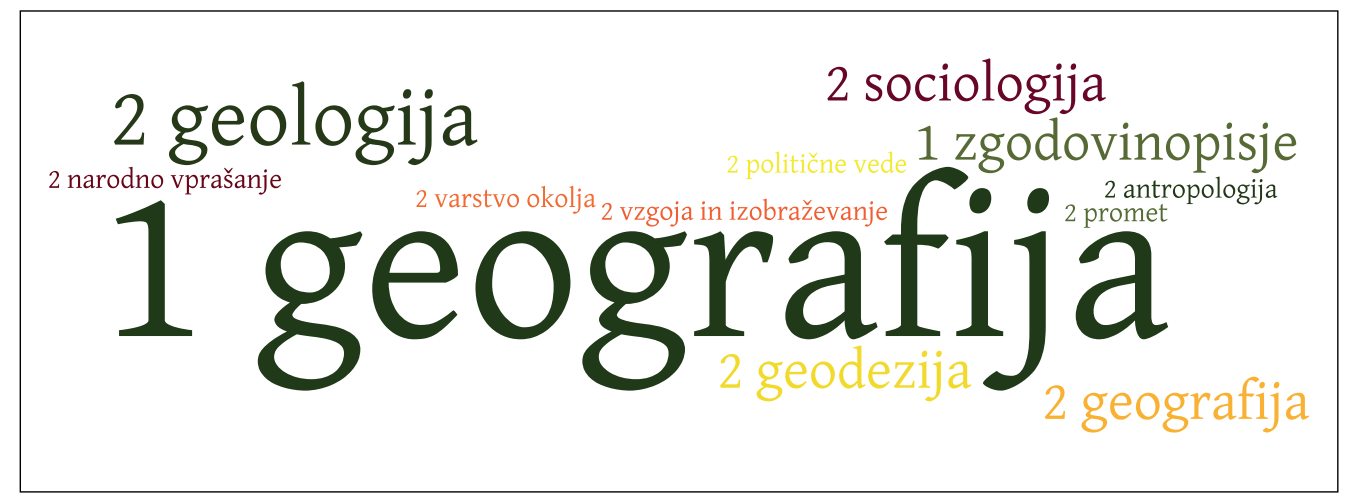

Slika 4: Deskriptorsko polje oblikovano iz področij, ki so bila navedena $v$ interdisciplinarnih predlogih ARRS-ja (1 pred področjem pomeni, da je bilo to področje vodilno, 2 pomeni, da je to področje nastopalo kot sodelujoče).

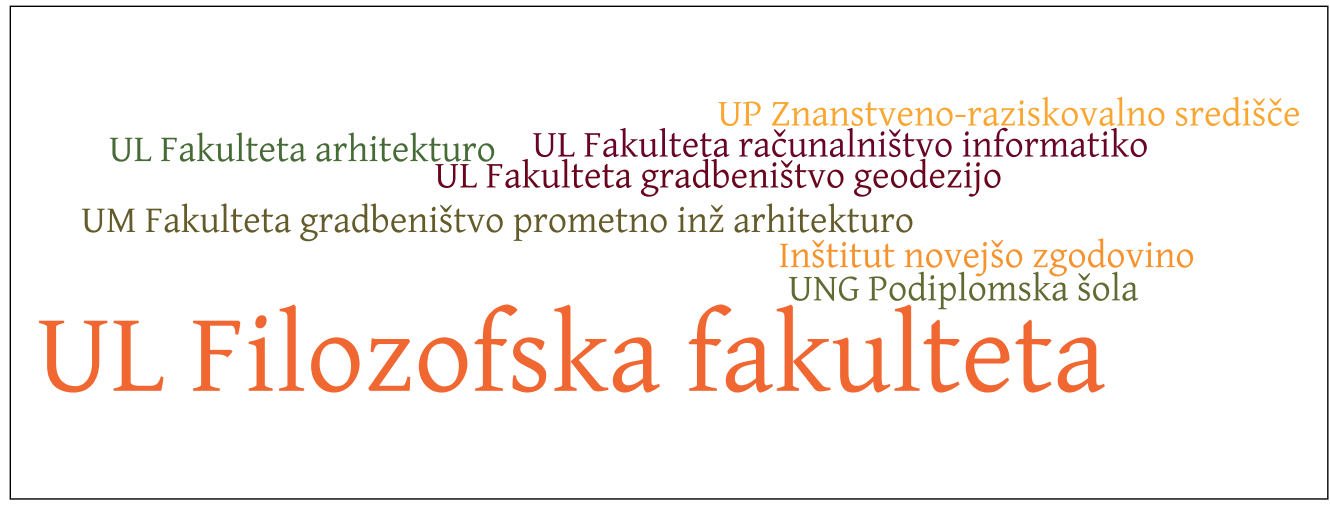

Slika 5: Sodelujoče ustanove pri prijavljenih projektih (uspelih in neuspelih) GIAM ZRC SAZU od 2011 dalje (iz imen ustanov so izpuščeni vezniki in členi, UL je Univerza $v$ Ljubljani, UM je Univerza v Mariboru, UNG je Univerza v Novi Gorici, UP je Univerza na Primorskem).

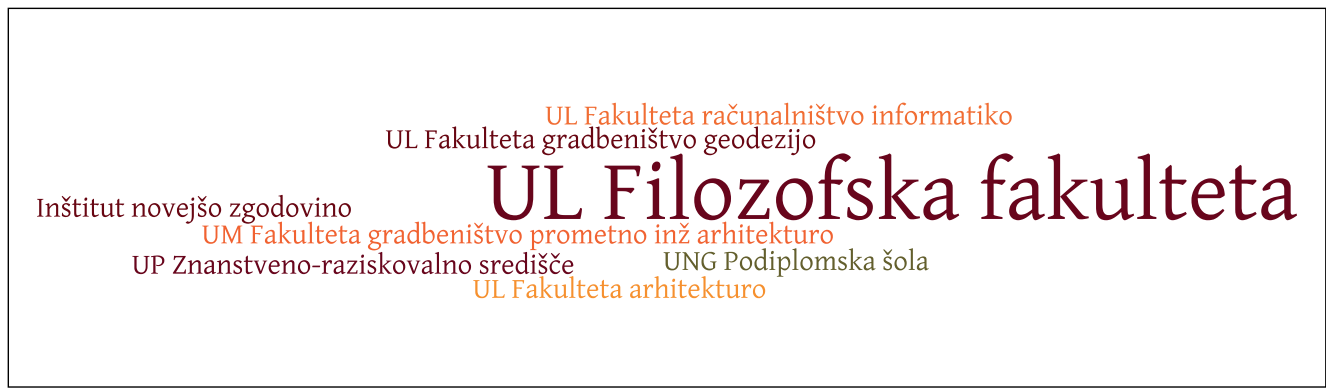

Slika 6: Sodelujoče ustanove na potekajočih projektih (iz imen ustanov so izpuščeni vezniki in členi, UL je Univerza v Ljubljani, UM je Univerza v Mariboru, UNG je Univerza v Novi Gorici, UP je Univerza na Primorskem). 


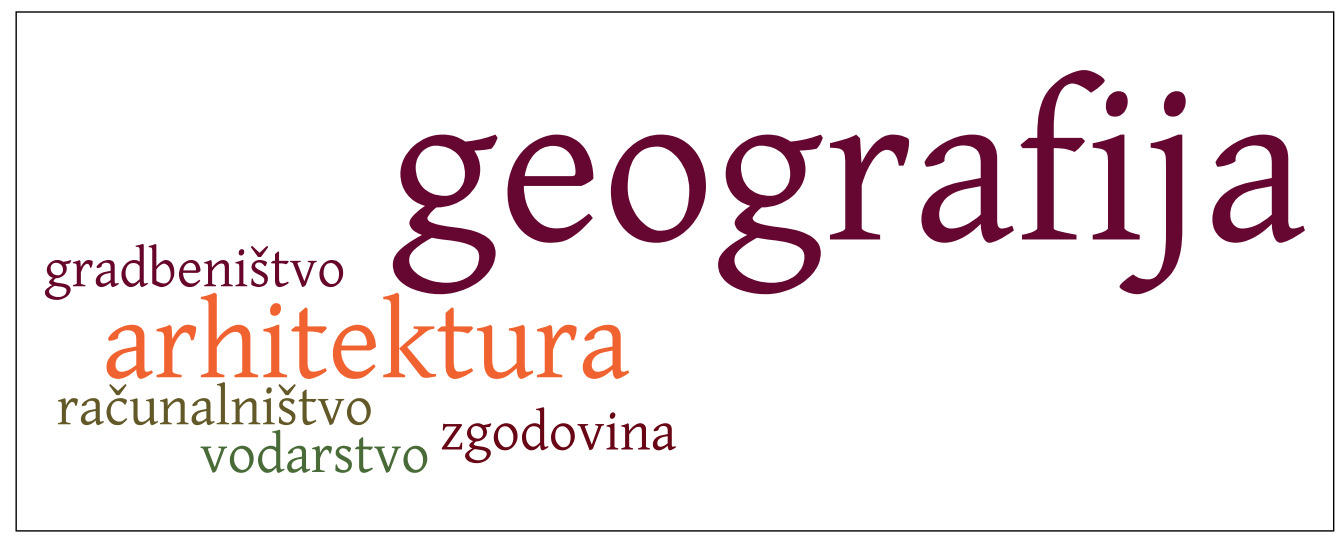

Slika 7: Področje vodilnega raziskovalca na ustanovah, s katerimi GIAM sodeluje pri projektih ARRS od leta 2011 dalje.

udejanjila na vseh ravneh do tolikšne mere, da v razpisih področja niso omenjena, zaradi česar je pogosto zelo težko razbrati, na katero področje razpisana tema sploh sodi.

Geografija se je uspela $\mathrm{z}$ drugimi ustanovami in področji povezati kljub formalni togosti sistema glede indisciplinarnosti. Pred leti je ARRS uvedla sistem »sodelujoče ustanove«, ki je zahteval, da mora biti v vsak projekt ustanove prijaviteljice vključena vsaj še ena ustanova. Interdisciplinarnost sicer ni bila pogoj, vendar je povezovanje pogosto temeljilo prav na njej. Slika 5 kaže povezovanje GIAM-a pri prijavljenih predlogih med letoma 2011 in 2017 (kot ustanova prijaviteljica in kot sodelujoča ustanova). Sicer se pri vseh ustanovah ne da razbrati, s katerega področja je sodelujoči raziskovalec (na primer pri Filozofski fakulteti), kljub temu pa slika daje vpogled v pestrost in interdisciplinarnost povezovanja.

Število in raznolikost sodelujočih ustanov se zmanjša na dejansko potekajočih projektih, kar kaže slika 6, vendar je interdisciplinarno sodelovanje dobro razvidno. Zanimivo je, da v vseh primerih, ko je GIAM sodelujoča ustanova, raziskovalna skupina prijaviteljica ni geografska.

Natančnejšo sliko interdisciplinarnosti dobimo, ko pogledamo področje vodilnega raziskovalca na ustanovah, s katerimi GIAM sodeluje pri projektih ARRS-ja (slika 7). Geografija po pričakovanjih prevladuje, med drugimi področji pa je vidna izrazita prevlada tehniških strok. Na projektni ravni geografija sodeluje s tehniškimi strokami in ne s področji, s katerimi se študijsko povezuje na domači Filozofski fakulteti.

\section{Projektno financiranje: ARRS projekti in tržni projekti}

Projektno oziroma kompetitivno financiranje znanosti je v Sloveniji prisotno že več kot dve desetletji in je primerljivo z drugimi državami v Evropi in zunaj nje. Razlika pa je v deležu bruto družbenega produkta (BDP), ki ga država namenja znanosti. »Barcelonski cilj kot del lizbonske strategije v državah EU postavlja za cilj vlaganje v znanost in razvoj v višini $3 \%$ BDP. Tretjina (1\%) teh vlaganj naj bi prišla iz javnih sredstev, dve tretjini (2\%) pa iz gospodarstva. Večina držav članic EU tega cilja še ne dosega, Slovenija bo ob trenutnih trendih cilj javnih vlaganj dosegla že do leta 2012 ... (Resolucija o ... 2011). Resolucija je bila sprejeta $\mathrm{v}$ finančno neugodnem obdobju in od sprejetja dalje so se sredstva za znanost neprestano krčila. Po intenzivnih prizadevanjih, zlasti Shoda za znanost, je Vlada Republike Slovenije

Slika 8: Primerjava prijavljenih (rdeči in modri stolpec) in odobrenih (oranžni in sivi stolpec) projektov s področja geografije in zgodovinopisja med letoma 2009 in 2015 (leta 2013 razpisa ni bilo; vir: ARRS). 


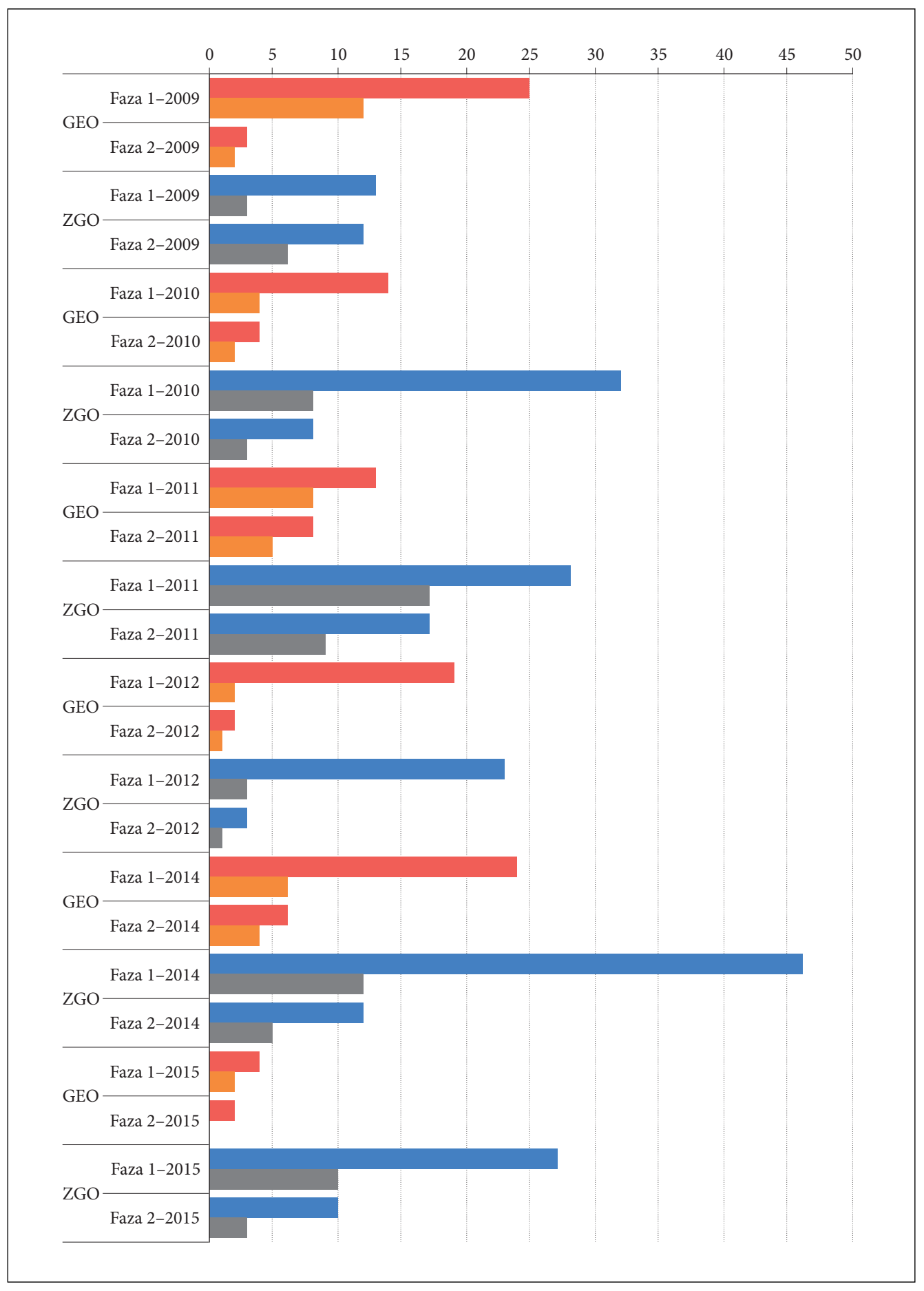


obljubila postopno povečevanje, ki naj bi do leta 2019 sredstva za znanost dvignilo do $1 \%$ BDP. Zmanjšana sredstva za znanost se zlasti občutijo v obsegu razpoložljivih sredstev vsakokratnega razpisa ARRS-ja za temeljne projekte. Posledično je stopnja uspeha nizka (slika 8), pri čemer pa geografija deli občo usodo znanosti (za primerjavo dajem zgodovinopisje).

Poleg nacionalnega financiranja in EU projektov, ki jim namenjam naslednje dve poglavji, omenjam še sklop tržnih projektov. Ker točne definicije tržnih projektov ni, jih vsak JRZ razume po svoje. To so manjši projekti s konkretno in zaokroženo nalogo za točno določenega naročnika. Javni sektor jih običajno oblikuje prek javnega naročila. Slika 2 kaže, da se njihov delež zmanjšuje, slika 9 pa kaže naročnike tržnih projektov med letoma 2005 in 2016.

\section{Vključenost geografije in geografov $v$ EU projekte}

EU projekti so postali stalnica v financiranju programov različnih sektorjev, ne le raziskovalnega. Odločitev raziskovalne skupine za sodelovanje je odvisna od več dejavnikov, povezanih z željami in potrebami raziskovalnih ustanov. Na eni strani stoji želja po povezovanju, sodelovanju, prenosu izkušenj in generiranju novega znanja, kar vodi k rasti raziskovalne skupine in njenem uveljavljanju ali h krepitvi določene vsebinske usmeritve oziroma oblikovanju nove. Gonilo »najboljših « projektov, na primer projektov Evropskega raziskovalnega sveta, je lahko tudi prestiž. Na drugi strani so potrebe ustanove oziroma posamezne raziskovalne skupine po finančnih sredstvih za raziskovalno delo in diseminacijo rezultatov. Želje in potrebe raziskovalne skupine sobivajo z željami ter potrebami države in družbe, ki želita tako odlično znanost kot value for money, torej največjo vrednost za porabljena javna sredstva. Potrebe države in družbe so številne: izvedljive, cenovno ugodne in družbeno sprejemljive tehnološke rešitve, delovna mesta $\mathrm{z}$ veliko dodano vrednostjo, trajnostni razvoj, zdravo, humano in etično, vključujočo in kritično razmišljujočo družbo in družbeno blaginjo, če naštejemo le nekatere.

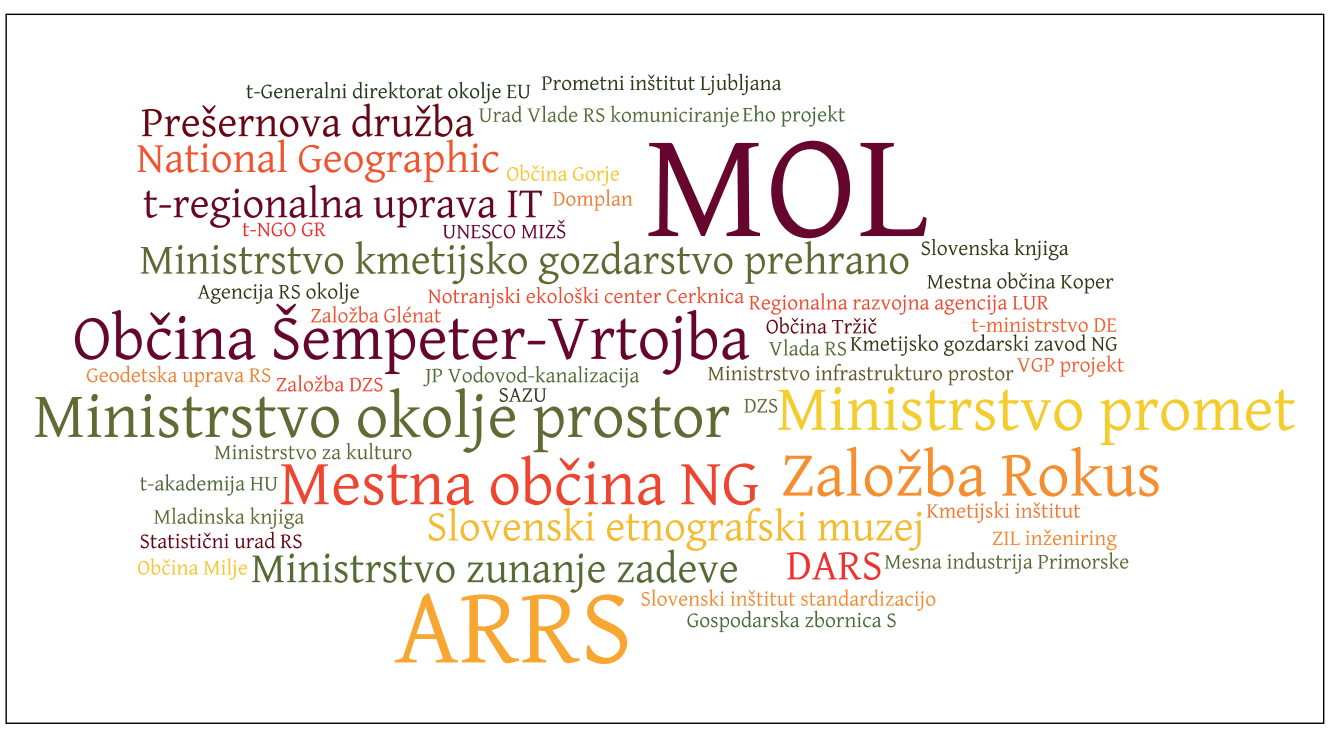

Slika 9: Deskriptorsko polje, oblikovano iz imen naročnikov tržnih projektov iz obdobja med 2005 in 2016 (MOL je Mestna občina Ljubljana, RS je Republika Slovenija, NG je Nova Gorica, S je Slovenija; tuji naročniki so označeni šcrko t in so poimenovani zgolj s tipom ustanove, čemur sledi še oznaka države; iz imen naročnikov so izpuščeni vezniki in členi). 
Pred 15 leti, ko je slovenska znanost začela razmišljati o sodelovanju pri EU projektih, so se ti zdeli čarobna rešitev za omejena nacionalna sredstva. Uvodno navdušenje in optimizem sta sicer zaradi različnih dejavnikov, h katerim se vrnemo v nadaljevanju, hitro splahnela. Večina EU sredstev za znanost in razvoj je namenjena reševanju gospodarskih, družbenih, kulturnih in prostorskih izzivov, kar ni vedno in povsem združljivo s temeljnim programom, s katerim raziskovalne ustanove postavljajo svoje vsebinske usmeritve. Slednje dokazuje tudi primerjava slik 10 in 11.

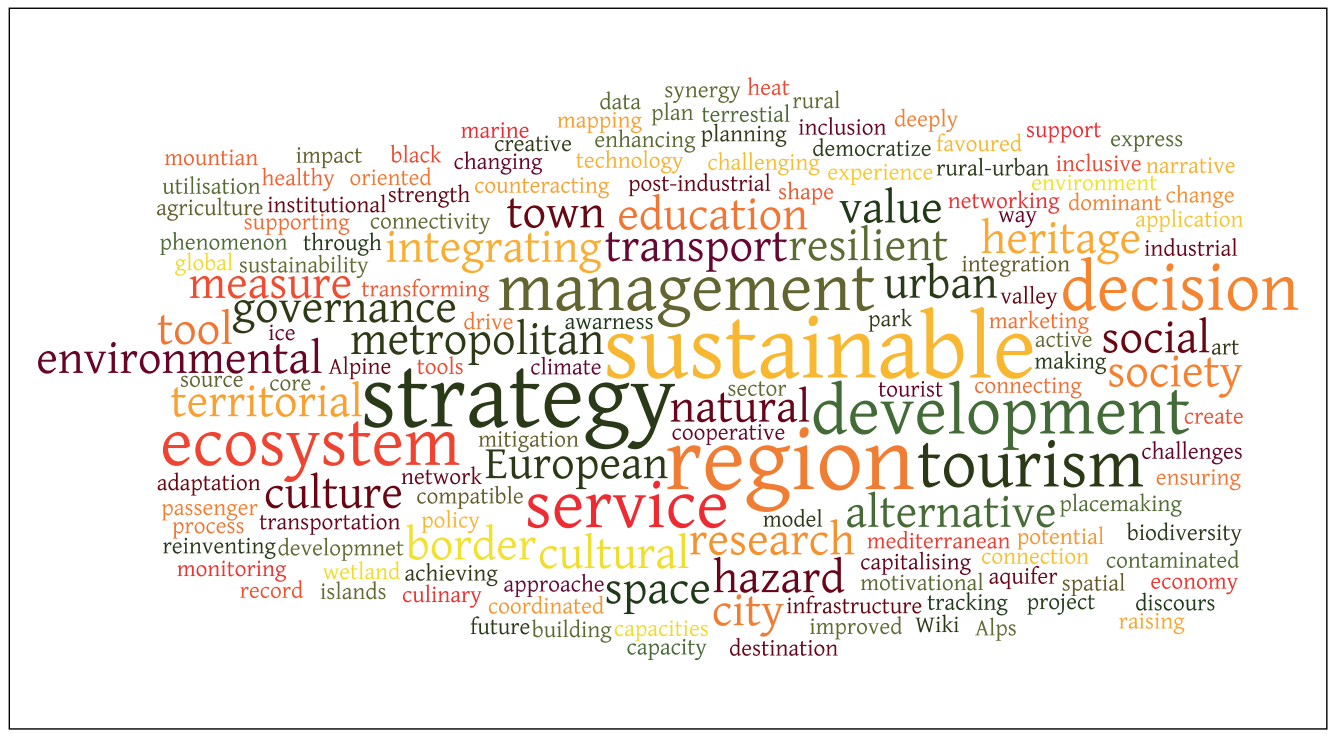

Slika 10: Deskriptorsko polje, oblikovano iz naslovov 23 uspelih EU projektov (končanih in potekajočih) 2005-2017, pri katerih sodeluje GIAM (iz pregleda so izločeni vezniki in členi, samostalniki so spremenjeni v edninsko obliko).

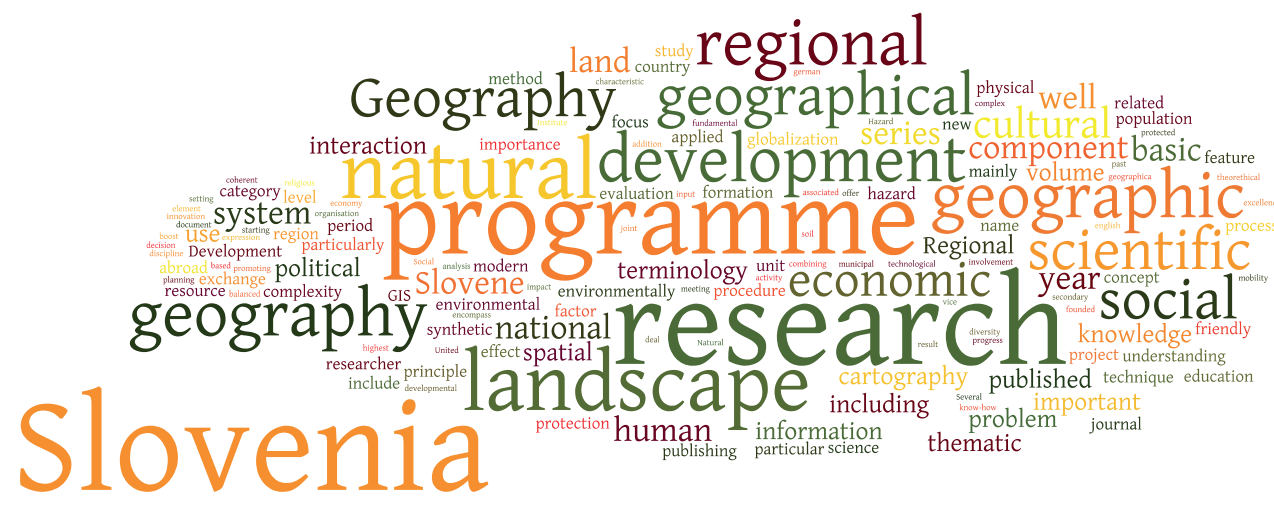

Slika 11: Deskriptorsko polje, oblikovano iz angleškega izvlečka dolgoročnega programa GIAM Geografija Slovenije (2009-2014 in 2015-2020) (iz pregleda so izločeni vezniki in členi, samostalniki so spremenjeni v edninsko obliko). 
EU projekti so pokazali univerzalno uporabnost geografije (in geografov), največ na račun njene interdisciplinarne narave, verjetno pa tudi zaradi veščin geografov. Debata, kaj je bilo prej, ali veščine ali študij geografije, je podobna debati o kokoši in jajcu. Razglabljanje o tem bom prihranila za drugič. Dejstvo je, da se je geografija v luči paradigme interdisciplinarnosti, relevantnosti in uporabnosti izkazala kot izjemno priročna, $\mathrm{k}$ čemur je prispeval tudi globalni premik v smeri iskanja relevantnosti, ki se je v geografiji zgodil v sedemdesetih letih prejšnjega stoletja (Bartel 2016). Geografi lahko sodelujemo v številnih programih, kar kaže preglednica 8 , ki je nastala na podlagi prijav (uspelih in neuspelih) med letoma 2005 in 2017 (presečni datum 1.9.2017) raziskovalne skupine GIAM.

Preglednica 8: EU raziskovalni in razvojni programi, v katerih lahko sodeluje geografska skupina, ter število prijav GIAM-a na posamezni program med letoma 2005 in 2017.

\begin{tabular}{llr}
\hline krovni program & program & število prijav \\
\hline centralizirani programi: & H2020 in okvirni programi & 29 \\
DG Research & Era-Net in JPI programi & 5 \\
& COST & 5 \\
\hline centralizirani programi: & ESPON & 2 \\
programi drugih DG & SME, Industry in Agri & 4 \\
& Aid programi & 4 \\
& Creative Europe programi & 4 \\
& Erasmus+ & 4 \\
\hline decentralizirani programi: & Life+ & 2 \\
kohezijski in strukturni programi & Interreg transnacionalni programi & 57 \\
& Interreg čezmejni programi & 11 \\
& Interreg interregionalni programi & 3 \\
\hline
\end{tabular}

Interdisciplinarnost je z vključevanjem v EU projektni prostor dobila povsem novo dimenzijo. Ker so le redki EU projekti raziskovalni, se je nabor sodelujočih ustanov zelo razširil. Preglednica 9 kaže tipe ustanov, s katerimi GIAM sodeluje na teh projektih, preglednica 10 pa njihovo število po državah.

Preglednica 9: Število in tip ustanov, s katerimi GIAM sodeluje na EU projektih.

\begin{tabular}{lc} 
tip partnerske ustanove & število ustanov \\
\hline R\&D (raziskave in razvoj) & 41 \\
lokalna oblast & 16 \\
zasebni neprofitni zavod & 14 \\
regionalna oblast & 11 \\
razvojna agencija & 7 \\
NGO (nevladne organizacije) & 4 \\
SME (mala in srednje velika podjetja) & 3 \\
javni zavod park & 3 \\
javna agencija & 2 \\
javni zavod muzej & 1 \\
mednarodna organizacija & 3 \\
SKUPAJ & $\mathbf{1 0 5}$ \\
\hline
\end{tabular}


Preglednica 10: Število ustanov, s katerimi GIAM sodeluje pri EU projektih po državah.

\begin{tabular}{lcccccccc}
\hline $\begin{array}{l}\text { država } \\
\text { število } \\
\text { partnerjev }\end{array}$ & Avstrija & Belgija & Bolgarija & Ciper & Češka & Danska & EU & Finska \\
$\begin{array}{l}\text { država } \\
\text { število } \\
\text { partnerjev }\end{array}$ & Francija & Grčija & Hrvaška & Italija & Latvija & Litva & Madžarska & Malta \\
$\begin{array}{l}\text { država } \\
\text { število } \\
\text { partnerjev }\end{array}$ & Makedonija & Nemčija & Nizozemska & Norveška & Poljska & Portugalska Romunija & Slovaška \\
$\begin{array}{l}\text { država } \\
\text { število } \\
\text { partnerjev }\end{array}$ & Slovenija & Švedska & Španija & Švica & $\begin{array}{l}\text { Združeno } \\
\text { kraljestvo }\end{array}$ & & & \\
\hline
\end{tabular}

V luči finančne perspektive 2014-2020 in področij politik Evropske unije preglednica 11 kaže, da geografska skupina najde priložnosti v vseh vsebinskih področjih politik Evropske unije, torej v štirih od skupno šestih področij. Priložnosti so na prvi pogled številne in zelo raznolike, vendar je pri tem treba upoštevati neverjetno konkurenco. Zaradi velikega števila potencialnih upravičencev so na videz zelo obsežna sredstva precej omejena. Posledično je nizka tudi stopnja uspešnosti: $10 \% \mathrm{v}$ centraliziranih programih Generalnega direktorata (GD) Raziskave (okvirni programi, H2020, COST, JPI in ERA-NET programi), $12 \% \mathrm{v}$ centraliziranih programih drugih generalnih direktoratov (na primer ESPON, SME, Aid, Creative Europe) in $23 \%$ v decentraliziranih programih Evropskega teritorialnega sodelovanja (Interreg). Dejanski odstotek je verjetno še nižji, saj podatki o neuspelih predlogih niso popolni.

Slika 12 kaže, v katerih programih je raziskovalna skupina GIAM dejansko sodelovala oziroma še sodeluje (2005-2017). Očitna je prevlada projektov Evropskega teritorialnega sodelovanja (v nadaljevanju

Preglednica 11: Področja politik EU in z njimi povezani raziskovalni in razvojni programi, $v$ katerih geografi lahko sodelujemo.

področja politik

programi

\section{Smart and Inclusive Growth}

1.a Competitiveness for growth and jobs

1.b Economic, social and territorial cohesion

2. Sustainable Growth: Natural Resources

3. Security and Citizenship
Horizon 2020 (COST, ERA-NET, JPI)

Erasmus+

Territorial cooperation (Interreg)

Cohesion fund

LIFE+: Environment and Climate Action

Europe for Citizens

Creative Europe

Humanitarian Aid

Pre-accession instrument

(povezuje se s teritorialnim sodelovanjem)

5. Administration

6. Compensations 


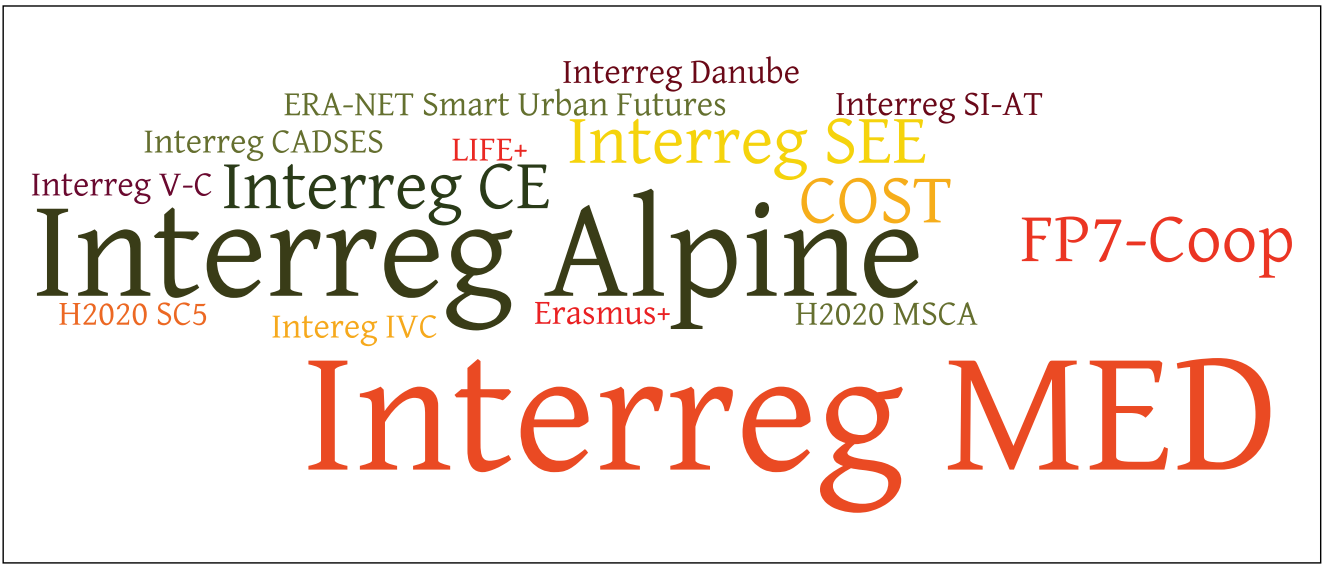

Slika 12: Programi, v katerih je sodelovala oziroma še sodeluje raziskovalna skupina GIAM med letoma 2005 in 2017.

Interreg). Eden od razlogov, a nikakor ne edini, je višja splošna stopnja uspešnosti na teh razpisih. Omenjena skupina je na pot EU projektov stopila ravno s tovrstnimi projekti, in sicer v programih Alpski prostor in CADSES (območje srednje in jugovzhodne Evrope). Številni institucionalni stiki z ustanovami s tega prostora niso nepomembni. Projekti, ideje in sodelovanja generirajo nove projekte. Pomembno je tudi dejstvo, da so tematike, ki jih naslavljajo Interreg programi (prostorski izzivi, regionalne politike ter naravna in kulturna dediščina) po svojem bistvu geografsko opredeljene. Pri tem pa naj kot zanimivost omenim, da raziskovalna skupina GIAM ni našla svojega mesta v programu ESPON, najbolj geografskem programu v EU.

Stopnja uspešnosti je zelo padla pri projektih GD Raziskave, ki bi morali tvoriti glavnino EU projektnega portfelja vsake raziskovalne skupine, saj so to raziskovalni projekti, večinoma namenjeni raziskovalnim in visokošolskim ustanovam. Zaradi nizke stopnje uspešnosti v programu H2020 opažam zadržanost oziroma pomanjkanje volje za pripravo tovrstnih predlogov. Obenem podatki na vseevropski ravni kažejo, da je program H2020 old boys's game, oziroma, da se sredstva zgoščajo pri največjih ustanovah z zahoda in severa Evrope. Ko je bila ob pripravi programa H2020 prvič omenjena možnost 100 \% financiranja, je raziskovalni svet zajelo skoraj evforično navdušenje. Toda posledica je bila manj odobrenih projektov za enak obseg sredstev, kar je spremljal še izrazit trend k večjim projektom. Sredstva za majhne ustanove iz politično šibke in nevplivne države »nove« Evrope so dokaj omejena.

\section{Umeščanje EU projektov v temeljno raziskovalno delo?}

EU projekti se precej razlikujejo od nacionalnih temeljnih projektov. Temeljno raziskovanje je $\mathrm{cu}$ riosity driven research, ki zahteva in spodbuja kreativnost, inovativnost in tveganja. Takšne raziskave zahtevajo miselne postopke na visoki ravni in notranje vrednotenje - raziskovalec oziroma skupina sama postavljata kriterije kakovosti. Aplikativne raziskave so challenge-driven research, pri katerih vsebino in kriterije postavlja naročnik. Delo in procesi se umaknejo zahtevam naročnika. V resnici je meja med obema vrstama raziskav zelo zamegljena, zlasti v geografiji, dejstvo pa je, da aplikativne raziskave v EU projektih spremljajo številne administrativne in organizacijske naloge, ki raziskovalce odvračajo od osredotočenega raziskovalnega dela. Obenem pa delo na EU projektih generira nove veščine in znanja, ki jih je mogoče s pridom uporabiti pri temeljnem raziskovalnem delu. Ob ustrezni zasnovi projekta in 
preudarni organizaciji je delo na aplikativnih EU projektih mogoče lepo preplesti s temeljnim raziskovanjem in doseči tudi večji znanstveni učinek. Odličen primer je ZBORZBIRK (medmrežje 2), Interreg projekt Slovenija-Italija, ki ga je koordiniral Inštitut za slovensko narodopisje ZRC SAZU. ARRS ga je izbrala za dosežek Odlični v znanosti.

Neposredni pozitivni učinek EU projektov je večja mobilnost, ki jo omogoča in zahteva sodelovanje v mednarodni skupini, in večje število objav v angleščini. Na tem mestu ne želim odpreti razprave o jeziku, dejstvo pa je, da znanost presega nacionalne oziroma jezikovne meje in postaja globalizirana, pri čemer na področju znanosti globalizacijo razumem izključno pozitivno. Slovenski raziskovalci, še posebej tisti na ZRC SAZU - temeljno poslanstvo ZRC SAZU je namreč preučevanje slovenske naravne in kulturne dediščine -, imamo sicer odgovornost, da svoje rezultate objavljamo (tudi) v slovenščini. Ker niso vsi rezultati primerni za objavo v angleščini in ne vsi za objavo v slovenščini, je vsakič potrebna presoja o ustreznem jeziku publikacije.

Zaradi EU projektov se veča tudi število skupinskih objav, kar je v tujini že dolgo časa običajna praksa, čeprav humanistika pri tem zaostaja. Znanost ni več individualna, ampak skupinska dejavnost. Sodelovanje v EU projektih in stiki z mednarodnim okoljem - tudi onstran projektov - omogočajo slovenskim raziskovalcem, ki delajo na ozko specializiranem področju, da presežejo majhnost nacionalnega raziskovalnega prostora in v sodelovanju s tujimi kolegi dosežejo kritično maso. Tovrstne objave so zaradi novih dimenzij in dinamike, povezane s skupinskim delom, običajno zelo relevantne in imajo velik učinek, tudi zaradi izbrane revije, ki je običajno zunaj siceršnjega kroga revij, v katerem naši avtorji objavljajo (Palang in sodelavci 2006; Kuhlicke in sodelavci 2011; Rudbeck Jepsena in sodelavci 2015; Admiraal in sodelavci 2017; Van den Born in sodelavci 2017).

EU projekti lahko odprejo novo področje oziroma v že uveljavljena področja vnesejo nove vidike in koncepte. Večina EU programov zasleduje princip top-down in v raziskovanje prinaša aktualnost. Ne trdim, da je zasledovanje modnih tem $\mathrm{v}$ znanosti vedno in povsod dobrodošlo, sem pa prepričana, da ob primerni vpetosti v siceršnje bolj dolgoročno zasnovane tematike lahko prinese pozitivne rezultate. V luči poslanstva ZRC SAZU je usmeritev h kulturni dediščini, ki je na GIAM prišla z EU projekti, povsem razumljiva in logična. Kulturna dediščina je bila že prej predmet raziskav, vendar v okviru drugih konceptualnih tradicij, zlasti pod krovnim konceptom kulturne pokrajine. Koordinatorski projekt Interreg Jugovzhodna Evropa Sy_cultour je prinesel vrsto izvirnih znanstvenih člankov v tujih revijah (Šmid Hribar, Bole in Pipan 2015; Bole, Šmid Hribar in Pipan 2017) in dveh tematskih številkah Acte geographice Slovenice (Bigaran, Mazzola in Stefani 2013; Dragićević in sodelavci 2013; Nared, Erhartič in Razpotnik Visković 2013; Šmid Hribar in Ledinek Lozej 2013; Blešić in sodelavci 2014; Klinar in Geršič 2014; Loulanski in Loulanski 2014; Stojanović 2014). Prav tako je dve tematski številki v omenjeni reviji prinesel tudi projekt Interreg Alpski prostor Wikialps (Brozzi in sodelavci 2015; Marzelli in Lintzmeyer 2015; Nared, Razpotnik Visković in Komac 2015; Nared in sodelavci 2015). Delo na področju kulturne dediščine so dopolnili še drugi projekti in objave, tudi monografije (Nared in Razpotnik Visković 2014a; Nared in Razpotnik Visković 2014b) in članki zunaj omenjenih projektov (na primer Dragićević in sodelavci 2015).

Če zmorejo raziskovalci znanje in empirične podatke, pridobljene v EU projektih, vpeti v določen konceptualni in metodološki okvir, lahko nastane dober članek ali študija s precejšnjim učinkom. Naj navedem nekaj primerov. V okviru projekta DIAMONT iz programa Interreg Alpski prostor, prvega večjega EU projekta GIAM-a, je nastala vrsta znanstvenih objav: monografija v tujem soavtorstvu izdana v tujini (Zumaglini in sodelavci 2008), monografija izdana pri Založbi ZRC (Razpotnik Visković, Urbanc in Nared 2013) in več znanstvenih člankov (Urbanc, Boesch in Jelen 2007; Razpotnik Visković, Nared in Urbanc 2008; Urbanc, Perko in Petek 2008). Še širše razsežnosti je imel projekt Interreg program CADSES R.A.V.E. Space. Poleg nekaj objav (Resnik Planinc 2006; Fridl in Urbanc 2008; Resnik Planinc 2008a; Resnik Planinc 2008b; Fridl, Urbanc in Pipan 2009; Urbanc in Fridl 2012) je projekt dobil nadgradnjo v novih aktivnostih, ki so pripeljale do predloga za prenovo učnega načrta in uresničitve tega predloga. Obenem je ta projekt pripeljal do zelo plodnega sodelovanja med udeleženima 
skupinama na GIAM-u in Oddelku za geografijo Filozofske fakultete Univerze v Ljubljani. Naj omenim še projekt Interreg Evropa $C A T C H-M R$ na temo prometa $\mathrm{z}$ dvema znanstvenima monografijama (Nared in Razpotnik Visković 2012; Nared in sodelavci 2012) in enim znanstvenim člankom (Bole in sodelavci 2012), ki so nadgradili dosedanje delo GIAM-a na področju prometa in mobilnosti. Rezultati so bili predstavljeni tudi na dveh konferencah, od katerih je bila ena zunaj Evrope. V projektu UHI, Interreg Srednja Evropa, so sodelavci GIAM-a objavili en znanstveni članek v tujini (Komac in Ciglič 2014) in 4 poglavja v knjigah (Komac in sodelavci 2016; Baranka in sodelavci 2016; Komac 2017; Komac in sodelavci 2017), pri čemer sta dve od teh knjig izšli pri priznani mednarodni založbi.

Vidna je razlika med objavami iz projektov 7. Okvirnega programa (7. OP) in Interreg projekti, ki so najbolje zastopani na GIAM-u. V okviru prvih je sicer nastalo manj objav, vendar gre večinoma za objave v prestižnih tujih revijah. Avtorjev takšnih člankov je po več kot 10 in praviloma so odlično citirani. V ospredju je motiv po objavi v najboljši mogoči mednarodni reviji za zgolj akademsko ciljno publiko. Rezultati Interreg projektov so pogosteje objavljeni v revijah in publikacijah sodelujočih ustanov, še največ pri Založbi ZRC. Pomemben motiv je pripeljati nove tuje avtorje in relevantne članke, ki gradijo podobo revij in založb sodelujočih ustanov, ciljna publika pa se razširi iz akademske sfere na širši krog strokovne javnosti. EU projekti spodbujajo objavo rezultatov, v manjši meri - z izjemo 7 . OP in H2020 -, če bi sklepali zgolj na osnovi objav, pa gradijo znanstveno odličnost. Navezujoč se na preglednico 2, so sodelavci GIAM-a v obdobju 2006-2017 objavili 4 članke v tujih revijah, ki po kriterijih ARRS štejejo za izjemne, pri čemer je eden od njih rezultat dela na projektu 7 . OP in trije rezultat dela na ARRS programu in projektih. Tudi od 11 člankov, ki sodijo v prvi kvartal revij, je le eden od člankov rezultat dela na projektu 7 . OP.

Družbeni učinek in pozitiven vpliv EU projektov na podobo ustanove pogosto presegata znanstveni učinek. V mislih imam predvsem aktivnosti in dogodke, ki sežejo prek dokaj ozkih okvirov same znanosti in imajo dolgoročne učinke. Naj omenim le nekatere. V okviru Interreg projekta SlovenijaAvstrija NH-WF - Naravne nesreče brez meja je bila vzpostavljena čezmejna mreža vremenskih in lavinskih opazovalnih postaj na območju Srednjih Karavank, ki omogoča pridobivanje obsežnih podatkov. Prav tako so bile opravljene LIDAR-ske raziskave in primerjava posnetkov kopnega in zasneženega površja, ki služijo oceni lavinske nevarnosti in modeliranju obsega posameznih snežnih plazov. Prek več Interreg projektov se je razvilo dolgoročno, plodno in večplastno sodelovanje z Občino Idrija, ki je prineslo vrsto rezultatov. Verjetno najpomembnejši je Inovativna strategija trajnostnega razvoja Občine Idrija (Nared in sodelavci 2011). Vzporedno in posledično z njo je nastalo več znanstvenih publikacij (Nared in Perko 2010; Urbanc, Nared in Bole 2012; Nared, Erhartič in Razpotnik Visković 2013). Za delo na Interreg projektu Sredozemlje 2Bparks je GIAM leta 2015 prejel prvo nagrado za projekt OkljukInterpretacijski poligon kot orodje za razumevanje kulturne pokrajine, ki jo je podelila Estonska univerza za znanosti o življenju na mednarodnem natečaju za pokrajine. Tudi že omenjeni projekt Sy_cultour je dobil mednarodno priznanje za dosežke pri varovanju in promociji kulturne dediščine, in sicer posebno omembo žirije Europa Nostra. Prav tako je bila za potrebe omenjenega projekta razvita metoda participativnega načrtovanja, ki so jo uporabile tudi druge lokalne skupnosti in vsaj trije drugi EU projekti. Predstavljena je bila v dveh znanstvenih člankih v tujih revijah (Šmid Hribar, Bole in Pipan 2015; Bole, Šmid Hribar in Pipan 2017). V okviru projekta Interreg Srednja Evropa UHI je bil vzpostavljen spletni atlas Central-European urban heat island atlas s kartografskimi sloji, pomembnimi za razumevanje lastnosti mestnih toplotnih otokov na območju srednje Evrope. Prav tako so bili pripravljeni prvi ukrepi in koraki za zmanjšanje posledic toplotnega otoka v Ljubljani. V okviru projekta Interreg Sredozemlje OTREMED je bila oblikovana spletna platforma Orodje za strateško prostorsko načrtovanje v Sredozemlju (Zorn in sodelavci 2013). 


\section{Glavni izzivi}

\subsection{Institucionalno načrtovanje dela}

Glavni izzivi JRZ-jev kot delodajalcev so povezani z načrtovanjem dela, saj je poslovanje enačba $z$ veliko neznankami. Obseg sredstev vsakokratnega razpisa ARRS je odvisen od letnega državnega proračuna, ki pa je stvar politike. Sredstva posameznega resorja so v tesni povezanosti s politično močjo ministra. Ministrstvo, pristojno za znanost, ne sodi med državotvorne resorje in ni politično vplivno. Ministri, pristojni za znanost, običajno ne sodijo med najvplivnejše politike.

Dolgo časa je veljalo, da bodo EU programi zapolnili vrzel v nacionalnem financiranju. Tovrstna pričakovanja so se kmalu izkazala za povsem iluzorna. Nacionalno financiranje raziskovalne dejavnosti ostaja ključni vir po vsej Evropi: le $8 \%$ znanosti v EU-ju se financira iz skupnega proračuna; države članice so odgovorne za ohranjanje odlične temeljne znanosti. Šele s tem, nacionalno financiranim znanjem se rešujejo skupni evropski izzivi ter ustvarjajo novi proizvodi in storitve. Dostop do EU sredstev je zelo omejen in povezan $\mathrm{z}$ več izzivi. Med najpomembnejšimi so ohlapno določena dinamika razpisov, zelo nizka stopnja uspeha v nekaterih za geografijo ustreznih temah v H2020 (1 \%), netransparentnost izbirnih postopkov in navsezadnje razdelitev politične in ekonomske moči v EU.

Tudi če je raziskovalna skupina uspešna v pridobivanju projektov, je organiziranje dela zahtevno. Projektov ni nikoli ravno prav, vedno jih je preveč ali premalo. Tudi vsebina ni vedno najbolj zaželena. V takem okolju je zelo težko načrtovati delo in kadrovsko politiko. Zato raziskovalne skupine večinoma niso optimalno sestavljene. Veliko energije je bilo vložene v ohranjanje raziskovalnih delovnih mest, tudi na račun strokovnih. Raziskovalno delo lahko čuti posledice prizadevanj za finančno vzdržnost, saj se varčuje pri materialnih stroških, obenem pa visoko usposobljeni raziskovalci v najvišjih raziskovalnih nazivih opravljajo strokovne in administrativne naloge. Zato so nekatera dela preplačana in raziskovalne skupine "predrage«, kar ugotavljamo zlasti pri konkuriranju za tržne projekte.

\subsection{Stanje duha v družbi}

Gonilo znanosti bi morali biti radovednost in ustvarjalnost, financira pa se v glavnem reševanje izzivov. Največji dosežki (ki so nastali kot rezultat radovednosti) so k reševanju izzivov pripomogli šele z velikim zamikom. Naj omenim samo primer Michaela Faradaya, enega izmed pionirjev elektromagnetizma, ki ga je leta 1850 obiskal britanski minister za finance. Faraday mu je v svojem londonskem laboratoriju pokazal nekaj dih jemajočih poskusov z elektriko, ki je bila tedaj še velika novost. Po predstavitvi ga je minister vprašal o praktični vrednosti elektrike. Brez oklevanja je Faraday odgovoril: »Nekega dne, gospod, jo boste lahko obdavčili ...«. Tudi nekaj tako pomembnega, kot je elektrika, se je torej v svoji pionirski fazi zdelo povsem nekoristno.

EU deluje v okviru nekaj letnih strateških ciklov. Upravičeno se lahko vprašamo, ali vemo, kaj bodo izzivi po letu 2020. Tako se mnogim nosilcem odločitev v EU SSH in z njimi geografija zdi omejeno koristna, čeprav so izzivi sodobne Evrope v veliko večji meri družbeni, socialni in kulturni kot pa tehnološki. V Sloveniji je položaj še slabši, saj znanost kot celota nima ustreznega mesta v družbi (medmrežje 3), prav tako pa je zaznati izrazit antiintelektualizem (medmrežje 4). Samo hard sciences so videne kot prava znanost, SSH pa je percipirana kot precej nekoristna. Slovenija v tem ni osamljena. V Obzorju 2020 je eden izmed stebrov Prvenstvo industrije, pri čemer evropska družba že desetletja temelji na storitvenem sektorju. Slovenija je temu sledila: v Strategiji pametne specializacije skoraj ni prostora za SSH.

\subsection{Pridobivanje projektov je igra $\mathrm{z}$ majhno verjetnostjo in dobitek ni vedno v veselje}

Na splošno velja, da je najtežje projekt dobiti, vse ostalo pa je čisto veselje. To drži le deloma. Prijavna faza je res izjemno stresna, ker je njen uspeh povezan z zaposlitvijo in socialno varnostjo raziskovalcev. 
Toda tudi druga faza, torej izvedba projekta, je običajno stresna in naporna. Če zanemarimo vsebinsko delo v interdisciplinarni mednarodni skupini in s tem povezane izzive (na primer zamude, različni pristopi), administrativno izvajanje zahteva velik angažma. Eden večjih in žal ne redkih anahronizmov je, da se projekt formalno začne na dan objave rezultatov razpisa, včasih pa tudi prej.

JRZ-je vežejo pravila, ki veljajo za celotni javni sektor. Delovno-pravna in javno-finančna zakonodaja v Sloveniji ne upoštevata, da so raziskovalna dejavnost oziroma JRZ-ji financirani popolnoma drugače kot ostali del javnega sektorja. Zaključiti poslovno leto s pozitivno ničlo, pri čimer je uspeh na potekajočih ali prihodnjih razpisih popolna neznanka, je velik izziv. Poleg vseh nacionalnih omejitev in pravil nas pri izvajanju vežejo še pravila programa oziroma financerja. Zlasti zahtevna so ta pravila pri decentraliziranih programih oziroma tistih, ki jih finančno in vsebinsko pregleduje Služba Vlade Republike Slovenije za razvoj in evropsko kohezijsko politiko (SVRK) (Interreg). Ta služba se je postavila nad nacionalna pravila, jih zaostrila (na primer pri javnem naročanju) in rahlo modificirala za vsak program posebej. Ker moramo upoštevati interna pravila, državna pravila, pravila SVRK-a in pravila programov, je upravljanje projektov postalo administrativno in časovno zelo zahtevno. EU oziroma organi znotraj nje se niso bili sposobni poenotiti, kar na svoji koži občutimo upravičenci EU sredstev. Vsebina projektov je tako pogosto v ozadju administrativnih in formalnih zahtev.

\subsection{Ključni elementi projektnega sveta}

Življenje raziskovalcev je prepleteno z izjemno negotovostjo. Stalno prijavljanje na razpise jemlje dragocen čas. Prijave so vedno zahtevnejše in številčnejše, saj je konkurenca vedno večja. Gospodarjenje s časom je izjemno težavno: uskladiti čas za raziskovanje in publiciranje, ki se je zaradi globalne maksime publish or perish zelo razmahnilo, s prijavljanjem na projektne razpise ni preprosto. Tudi samo raziskovalno delo ni strnjeno in osredotočeno, saj večina raziskovalcev dela na več projektih z različno dinamiko hkrati. Še večji problem pa je, da so individualni in institucionalni raziskovalni interesi v senci predpisanih vsebin. Le ARRS projekti in programi omogočajo resno temeljno raziskovalno delo, velika večina EU projektov pa je aplikativnih. Vsak raziskovalec in vsaka raziskovalna skupina bi morala imeti različne vrste projektov, pri čemer pa bi temeljno raziskovanje moralo biti hrbtenica, ki nudi oporo in daje gradivo aplikativnim projektom. V zgornjih primerih sem pokazala nekatere odlične rezultate, ki so izšli iz EU projektov, vendar ima (pre)velik obseg aplikativnih projektov lahko dolgoročne negativne posledice. (Večina) aplikativnih projektov le v manjši meri gradi habitus raziskovalca, prav tako pa delo na njih zahteva drugačne miselne procese in dinamiko.

Geografija ima zahvaljujoč svoji multidisciplinarni naravi številne možnosti sodelovanja na EU projektih. Na primeru GIAM-ma in njegove tesne vpetosti v EU projekte sem pokazala, da jih tudi odlično izrablja. Multidisciplinarnost nudi številne priložnosti, a tudi pasti, zlasti izgubo fokusa. Raziskovalno delo je izjemno zahtevno tudi zaradi obilice novega znanja, ki dnevno nastaja po svetu. Vsako leto je objavljenih milijon člankov, kar pomeni, da jih je na vsakem še tako specialnem in ozkem področju nekaj deset. Samo branje teh nekaj deset člankov vzame veliko časa. Ozka usmerjenost in osredotočenost sta nujni za kakovostno raziskovalno delo.

\section{Sklep}

Raziskovalcev je več kot kdaj koli prej. Država vlaga velika sredstva v izobraževanje, obenem pa se ni prilagodila velikemu številu doktorandov. Raziskovalne ustanove same nosijo breme, da doktorande obdržijo, s čimer postavljajo socialni vidik pred znanost. Vključenost v EU raziskovalni prostor je zato zelo pomembna za finančno preživetje ustanov. Možnosti za geografijo v tem prostoru so številne zaradi njene interdisciplinarne narave. EU projekti imajo v večini primerov zelo pozitiven vpliv zaradi mreženja, povezovanja in sodelovanja $\mathrm{z}$ raziskovalnimi in drugimi ustanovami, ter zaradi novih pub- 
likacijskih poti in naraščanja števila objav v angleščini. Toda politika EU raziskovanje razume zgolj kot enega od servisov za reševanje kratkoročnih in srednjeročnih izzivov in deluje po principu "po uporabi zavrzi«. Znanost pa je izrazito dolgoročna in potrebuje stabilno okolje, v katerem je edino mogoče pričakovati ustvarjanje novega znanja. Prispevek EU projektov k razvoju stroke in strokovni rasti raziskovalcev je jasno razviden, njihov prispevek k razvoju odlične znanosti pa ni samoumeven in premočrten.

Ta prispevek izraža stališča avtorice in ne ustanove, na kateri je zaposlena.

Zahvala: Prispevek je nastal v okviru raziskovalnega program številka P6-0101, ki ga sofinancira Javna agencija za raziskovalno dejavnost Republike Slovenije.

\section{Viri in literatura}

Admiraal, J., Van den Born, R., Beringer, A., Bonaiuto, F., Cicero, L., Hiedanpää, J., Knights, P., Knippenberg, W. J. L., Molinario, E., Musters, C. J. M., Naukkarinen, O., Polajnar Horvat, K., Popa, P., Smrekar, A., Soininen, T., Porras-Gomez, C., Soethe, N., Vivero-Pol, J. L., Wouter, T. de G. 2017: Motivations for committed nature conservation action in Europe. Environmental Conservation 44-2. DOI: https://doi.org/10.1017/S037689291700008X

ARRS 2017. Medmrežje: https://www.arrs.gov.si/sl/ (27.11.2017).

Baerwald, T. J. 2010: Prospects for geography as an interdisciplinary discipline. Annals of the Association of American Geographers 100-3. DOI: https://doi.org/10.1080/00045608.2010.485443

Banski, J. 2012: The position of geography in the organizational structure of selected academic institutions around the world. Przeglad Geograficzny 84-2.

Banski, J. 2013: Geography in the organizational structure of academic institutions - selected issues. European Journal of Geography 4-2.

Baranka, G., Bozó, L., Ciglič, R., Komac, B. 2016: Urban heat island gold standard and urban heat island atlas - gold standard for UHI Measurements and Introduction of the Central-European urban heat island atlas. Counteracting Urban Heat Island Effects in a Global Climate Change Scenario. Cham. DOI: https://doi.org/10.1007/978-3-319-10425-6_2

Bartel, R. 2016: Legal geography, geography, and the research-policy nexus. Geographical Research 54-3. DOI: https://doi.org/10.1111/1745-5871.12159

Baškovič, C. 2016: Rojstvo programa mladih raziskovalcev. Kvakadabra - časopis za tolmačenje znanosti. Medmrežje: http://www.kvarkadabra.net/2016/10/rojstvo-programa-mladih-raziskovalcev/ (20.9.2017).

Bauder, H. 2015: The international mobility of academics: A labour market perspective. International Migration 53-1. DOI: https://doi.org/10.1111/j.1468-2435.2012.00783.x

Bigaran, F., Mazzola, A., Stefani, A. 2013: Enhancing territorial capital for developing mountain areas: the example of Trentino and its use of medicinal and aromatic plants. Acta geographica Slovenica 53-2. DOI: https://doi.org/10.3986/AGS53403

Blešić, I., Pivac, T., Đorđević, J., Stamenković, I., Janićević, S. 2014: Cultural events as part of cultural tourism development. Case study: Sombor and Apatin (Serbia). Acta geographica Slovenica 54-2. DOI: https://doi.org/10.3986/AGS54406

Bole, D., Gabrovec, M., Nared, J., Razpotnik Visković, N. 2012: Integrated planning of public passenger transport between the city and the region: the case of Ljubljana. Acta geographica Slovenica 52-1. DOI: https://doi.org/10.3986/AGS52106

Bole, D., Šmid Hribar, M., Pipan, P. 2017: Participatory research in community development: a case study of creating cultural tourism products. Acta Universitatis Carolinae Geographica 52-2. DOI: https://doi.org/10.14712/23361980.2017.13 
Brozzi, R., Lapuh, L., Nared, J., Streifeneder, T. 2015: Towards more resilient economies in Alpine regions. Acta geographica Slovenica 55-2. DOI: https://doi.org/10.3986/AGS.916

COBISS 2017. Medmrežje: http://www.cobiss.si/ (27.11.2017).

Dragićević, V., Besermenji, S., Pivac, T., Ivkov-Džigurski, A., Košićanja, K. 2013: Evaluation of tourist attractiveness and museum management in Sombor and Apatin (Serbia). Acta geographica Slovenica 53-2. DOI: https://doi.org/10.3986/AGS53405

Dragićević, V., Bole, D., Bučić, A., Prodanovič, A. 2015: European capital of culture: residents' perception of social benefits and costs - Maribor 2012 case study. Acta geographica Slovenica 55-2. DOI: https://doi.org/10.3986/AGS.747

Fridl, J., Urbanc, M. 2008: Kartografski in drugi grafični prikazi kot nepogrešljiva učila pri izobraževanju za trajnostni razvoj. Geodetski vestnik 52-4.

Fridl, J., Urbanc, M., Pipan, P. 2009: The importance of teachers' perception of space in education. Acta geographica Slovenica 49-2. DOI: https://doi.org/10.3986/AGS49205

Hall, T., Toms, P., McGuinness, M., Parker, C., Roberts, N. 2015: Where's the geography department? The changing administrative place of geography in UK higher education. AREA 47-1. DOI: https://doi.org/10.1111/area.12154

Klinar, K., Geršič, M. 2014: Traditional house names as part of cultural heritage. Acta geographica Slovenica 54-2. DOI: https://doi.org/10.3986/AGS54409

Komac, B. 2017: Prožna mesta - trajnostni razvoj in naravne nesreče. Trajnostni razvoj mest in naravne nesreče, Naravne nesreče 4. Ljubljana.

Komac, B., Ciglič, R. 2014: Urban heat island atlas: a web tool for the determination and mitigation of Urban Heat Island effects. Geographia Polonica 87-4.

Komac, B., Ciglič, R., Loose, A., Pavšek, M., Čermelj, S., Oštir, K., Kokalj, Ž., Topole, M. 2016: Urban heat island in the Ljubljana city. Counteracting Urban Heat Island Effects in a Global Climate Change Scenario. Cham. DOI: https://doi.org/10.1007/978-3-319-10425-6_12

Komac, B., Ciglič, R., Pavšek, M., Kokalj, Ž. 2017: Naravne nesreče v mestih - primer mestnega toplotnega otoka. Trajnostni razvoj mest in naravne nesreče, Naravne nesreče 4. Ljubljana.

Kuhlicke, C., Steinführer, A., Begg, C., Bianchizza, C., Bründl, M., Buchecker, M., De Marchi, B., Di Masso Tarditti, M., Höppner, C., Komac, B., Lemkow, L., Luther, J., McCarthy, S., Pellizzoni, L., Renn, O., Scolobig, A., Supramaniam, M., Tapsell, S., Wachinger, G., Walker, G., Whittle, R., Zorn, M., Faulkner, H. 2011: Perspectives on social capacity building for natural hazards: outlining an emerging field of research and practice in Europe. Environmental Science and Policy 14-7. DOI: https://doi.org/10.1016/j.envsci.2011.05.001

Loulanski, V., Loulanski, T. 2014: The heritization of Bulgarian rose. Acta geographica Slovenica 54-2. DOI: https://doi.org/10.3986/AGS54408

Marzelli, S., Lintzmeyer, F. 2015: Transnational needs of sustainable spatial development in the Alps: results from an analysis of policy documents. Acta geographica Slovenica 55-2. DOI: https://doi.org/10.3986/AGS.1585

Medmrežje 1: http://enressh.eu/ (27.11.2017).

Medmrežje 2: http://zborzbirk.zrc-sazu.si/sl-si/novice.aspx (27.11.2017).

Medmrežje 3: http://www.tromba.si/dr-edvard-kobal-v-sloveniji-znanost-se-vedno-nima-splosnopriznane-razvojne-vloge-in-mesta-v-druzbi/ (28.11.2017).

Medmrežje 4: https://marijanzlobec.wordpress.com/2017/09/13/slovenska-znanost-ne-bo-dobila-vecdenarja/ (27.11.2017).

Nared, J., Perko, D. (ur.) 2010: Na prelomnici: razvojna vprašanja občine Idrija. Capacities 1. Ljubljana.

Nared, J., Razpotnik Visković, N. (ur.) 2012: MOVING People: Towards Sustainable Mobility in European Metropolitan Regions. Potsdam.

Nared, J., Razpotnik Visković, N. (ur.) 2014a: Izbrani primeri upravljanja območij s kulturno dediščino. Capacities 3. Ljubljana. 
Nared, J., Razpotnik Visković, N. (ur.) 2014b: Upravljanje območij s kulturno dediščino. Capacities 2. Ljubljana.

Nared, J., Bole, D., Gabrovec, M., Geršič, M., Goluža, M., Razpotnik Visković, N., Rus, P. 2012: Celostno načrtovanje javnega potniškega prometa v ljubljanski urbani regiji. Georitem 20. Ljubljana.

Nared, J., Erhartič, B., Razpotnik Visković, N. 2013: Including development topics in a cultural heritage management plan: Mercury heritage in Idrija. Acta geographica Slovenica 53-2. DOI: https://doi.org/ 10.3986/AGS53404

Nared, J., Razpotnik Visković, N., Cremer-Shulte, D., Brozzi, R., Cortines Garcia, F. 2015: Achieving sustainable spatial development in the Alps through participatory planning. Acta geographica Slovenica 55-2. DOI: https://doi.org/10.3986/AGS.1631

Nared, J., Razpotnik Visković, N., Komac, B. 2015: The Alps: A physical geography, political, and program framework. Acta geographica Slovenica 55-1. DOI: https://doi.org/10.3986/AGS.1970

Nared, J., Smrekar, A., Bole, D., Kozina, J., Fridl, J., Polajnar Horvat, K., Gabrovec, M., Repolusk, P., Zavodnik Lamovšek, A., Sever, B., Gantar, D. 2011: Inovativna strategija trajnostnega razvoja Občine Idrija. Ljubljana.

Novak, P. 2016: Doktorji znanosti - po usposabljanju po programu mladih raziskovalcev in prijave na Zavodu RS za zaposlovanje, 2012-2015. Medmrežje: https://www.arrs.gov.si/sl/analize/inc/ Analize/DR-MR_2012-2015.pdf (15.11.2017).

Palang, H., Printsmann, A., Konkoly Gyuró, É., Urbanc, M., Skowronek, E., Woloszyn, W. 2006: The forgotten rural landscapes of Central and Eastern Europe. Landscape ecology 21-3. DOI: https://doi.org/10.1007/s10980-004-4313-x

Perko, D. 2010: Analiza geografskih bibliografskih enot glede na pravila javne agencije za raziskovalno dejavnost Republike Slovenije. Geografski vestnik 82-2.

Perko, D., Zorn, M. 2016: Sedemdeset let raziskovanj na Geografskem inštitutu Antona Melika ZRC SAZU. Geografski vestnik 88-2. DOI: https://doi.org/10.3986/GV88207

Poročilo o delu ZRC SAZU 2006, 2010, 2012, 2014 in 2016. Ljubljana.

Pravilnik o postopkih (so)financiranja in ocenjevanja ter spremljanju izvajanja raziskovalne dejavnosti, 2016. Medmrežje: http://www.arrs.gov.si/sl/akti/prav-sof-ocen-sprem-razisk-dej-avg2016.asp (15.11.2017).

Razpotnik Visković, N., Nared, J., Urbanc, M. 2008: Pogovor v kavarni: soočenje teorije in prakse. Geografski vestnik 80-1.

Razpotnik Visković, N., Urbanc, M., Nared, J. 2013: Prostorska in razvojna vprašanja Alp. Georitem 12 Ljubljana.

Resnik Planinc, T. 2006: Vrednote prostora kot integralni del izobraževanja. Geografski vestnik 78-2.

Resnik Planinc, T. 2008a: Geographical education and values of space: a comparative assessment from five European countries. International Research in Geographical and Environmental Education 17-1. DOI: https://doi.org/10.2167/irgee228.0

Resnik Planinc, T. 2008b: Vrednote prostora v procesu geografskega izobraževanja. Dela 29. DOI: https://doi.org/10.4312/dela.29.2.21-35

Resolucija o raziskovalni in inovacijski strategiji Slovenije 2011-2020 (ReRIS11-20), 2011. Medmrežje: http://www.pisrs.si/Pis.web/pregledPredpisa?id=RESO68 (15.11.2017).

Rudbeck Jepsena, M., Kuemmerle, T., Müller, D., Erb, K., Verburg, P. H., Haberl, H., Vesterager, J. P., Andrič, M., Antrop, M., Austrheim, G., Björn, I., Bondeau, A., Bürgi, M., Bryson, J., Caspar, G., Cassar, L. F., Conrad, E., Chromý, P., Daugirdas, V., Van Eetve, V., Elena-Rosselló, R., Gimmi, U., Izakovicova, Z., Jančák, V., Jansson, U., Kladnik, D., Kozak, J., Konkoly-Gyuró, E., Krausmann, F., Mander, Ü., McDonagh, J., Pärn, J., Niedertscheider, M., Nikodemus, O., Ostapowicz, K., PérezSoba, M., Pinto-Correia, T., Ribokas, G., Rounsevell, M., Schistou, D., Schmit, C., Terkenli, T. S., Tretvik, A. M., Trzepacz, P., Vadineanu, A., Walz, A., Zhllima, E., Reenberg, A. 2015: Transitions in European land-management regimes between 1800 and 2010. Land Use Policy 49. DOI: https://doi.org/10.1016/j.landusepol.2015.07.003 
SICRIS 2017. Medmrežje: http://www.sicris.si/public/jqm/cris.aspx?lang=slv\&opdescr=home\&opt=1 (27.11.2017).

Stojanović, V., Đorđević, J., Lazić, L., Stamenković, I., Dragićević, V. 2014: The principles of sustainable development of tourism in the special nature reserve "Gornje Podunavlje « and their impact on the local communities. Acta geographica Slovenica 54-2. DOI: https://doi.org/10.3986/AGS54407

Šmid Hribar, M., Bole, D., Pipan, P. 2015: Sustainable heritage management: social, economic and other potentials of culture in local development. Procedia - Social and Behavioral Sciences 188. DOI: https://doi.org/10.1016/j.sbspro.2015.03.34410

Šmid Hribar, M., Ledinek Lozej, Š. 2013: The role of identifying and managing cultural values in rural development. Acta geographica Slovenica 53-2. DOI: https://doi.org/10.3986/AGS53402

Urbanc, M. 2008: Večdimenzionalnost pokrajine: primer slovenske Istre. Geografski vestnik 80-2.

Urbanc, M., Boesch, M., Jelen, I. 2007: Kultura in regionalna politika: kultura kot dejavnik regionalnega razvoja Alp. Geografski vestnik 79-1.

Urbanc, M., Fridl, J. 2012: Education for active citizenship in spatial-planning processes: from teacher to student. Geografski vestnik 84-1.

Urbanc, M., Nared, J., Bole, D. 2012: Idrija: a local player on the global market. Locality, Memory, Reconstruction: The Cultural Challenges and Possibilities of Former Single-Industry Communities. Newcastle upon Tyne.

Urbanc, M., Perko, D., Petek, F. 2008: Prihodnost Alp in delfi metoda. Geografski vestnik 80-2.

Van den Born, R., Arts, B., Admiraal, J., Beringer, A., Knights, P., Molinario, E., Polajnar Horvat, K., Porras-Gomez, C., Smrekar, A., Soethe, N., Vivero-Pol, J. L., Ganzevoort, W., Bonaiuto, M., Knippenberg, L., De Groot, W. T. 2017: The missing pillar: eudemonic values in the justification of nature conservation. Journal of Environmental Planning and Management 60-10. DOI: https://doi.org/ 10.1080/09640568.2017.1342612

Wainwright, E. 2015: Geographers out of place: institutions, (inter)disciplinarity and identity. AREA 56-4. DOI: https://doi.org/10.1111/area.12126

Zorn, M., Razpotnik Visković, N., Repolusk, P., Ferk, M. 2013: Prostorski in regionalni razvoj Sredozemlja - enotni pristop in izbrana orodja. Georitem 22. Ljubljana.

Zumaglini, M., Nared, J., Alfarè, L., Razpotnik Visković, N., Urbanc, M., Tappeiner, U. (ur.) 2008: Participation Process in Regional Development: DIAMONT's Perspective. Bolzano.

\section{Summary: (Un)limited opportunities for geography on the project market} (translated by DEKS d. o. o.)

Geography is a complex, eclectic, and applied discipline; as such, it ought to be highly valued in today's society and politics, which are marked by a desire to transcend the boundaries of disciplines, to cooperate, and to seek relevance and applicability. Consequently, geography should not have any existential problems. Whether this is the case demands careful consideration, which this article contributes to. It relies on freely available information from the Slovenian Research Agency (ARRS) and the SICRIS information system. In an effort to provide a concrete example, the article highlights the research group at the Anton Melik Geographical Institute (GIAM) of Research Centre of the Slovenian Academy of Sciences and Arts.

The fact that ARRS classifies geography under the humanities has a great impact on its position in the Slovenian scholarly system; this is probably also a consequence of geography being taught at university divisions dedicated to the humanities. The position of researchers at public research institutes is defined by the formal legal framework of the public sector, but they are the only civil servants without budgeted posts. This has given rise to a number of challenges, and at the same time there is no limit to their number as well as a job classification. The conceptual orientations of each research group 
are defined in the research program financed by ARRS. With some reservations, this could be termed institutional funding, which however does not cover much more than the minimum needs of a particular discipline. Competitive funding is therefore necessary for normal development of the field. Overall, the financial situation of research is poor, and it was exacerbated by the most recent economic crisis. After many efforts, it was agreed that public investment in research would rise to 1\% of GDP by 2019. Because of low investment, the success rate in national tenders is very low (Figure 8), whereby geography shares the general fate of scholarly disciplines, especially the humanities (e.g., history).

The quality of research work is a very complex issue. Here I offer only a few bibliometric indicators that broadly shed light on this aspect. Within Slovenian scholarship, in terms of citations geography research groups (two from research institutions and two from universities) rank highly (Figure 3) among the top twenty groups in the humanities (among 1,403 research groups altogether). Also as individuals, geographers are highly ranked on the scale of the top hundred researchers (Table 1). The total number of publications by research groups (Table 2) is large, but only rarely are these included in the top quarter of journals as indexed by SNIP and JCR. Slovenian geographical journals (Table 3) already made great progress in being included in appropriate indices, but with regard to their profile and quality there is still room for improvement.

Slovenian geographical research is characterized by an almost total lack of employment mobility. The employment market operates only from the perspective of being and remaining in the academic environment (Table 6), but within it there is hardly any mobility. The information on workplace mobility at GIAM shows that not all of the researchers are mobile and that EU projects (i.e., meetings) contribute greatly to mobility. Mobility varies from year to year and is connected with the financial situation. Extended research work abroad (i.e., more than a month) is more of an exception than a rule.

In addition to spatial mobility, interdisciplinarity is also important for the interchange of ideas, but it is inappropriately categorized under national research policy. The sharp and strict delimitation between individual fields is partially mitigated by the opportunity to apply for interdisciplinary projects, for which there is exceptionally little funding available. On this point, Slovenian research policy differs considerably from the predominant European and global concept of interdisciplinarity. Despite everything, applications for and the implementation of national projects involve cooperation with other institutions and other areas. For the most part, cooperation takes place with geographers, and beyond that more frequently with technical disciplines than the humanities.

EU projects have demonstrated the universal applicability of geography and geographers, or the possibility of cooperating in numerous programs (Table 8). Interdisciplinarity acquired a completely new dimension and an expanded range of participating institutions (Table 9). The opportunities are numerous and very diverse, but the competition is intense. As a result, the success rate is low, and for the GIAM research group it ranges from 10\% in DG Research programs (framework programs, H2020, COST, JPI, and Era Net) to $23 \%$ in the decentralized European territorial cooperation (Interreg) programs. The strong inclusion of GIAM in the Interreg projects is therefore no surprise (Figure 12). Among the reasons for this, it is also worth mentioning the topics (spatial challenges, regional policies, and natural and cultural heritage) and modus operandi of these projects, which are a good match for geographers. At the same time, there has been a marked decrease in the success of projects in the H2020 program, which ought to form the main part of every research group's EU project portfolio. Consequently, I see reservation or lack of will to prepare these kinds of proposals. The information for the pan-European level shows that the H2020 program is an »old boys' game, " or that funds are concentrated in the largest institutions from western and northern Europe. The opportunities for smaller institutions from the politically weak and uninfluential countries of the "new « Europe are rather limited.

EU projects differ considerably from basic national projects. These involve curiosity-driven research, which demands and promotes creativity, innovation, and risk. Applied research is challenge-driven research, in which the demands of the client are at the forefront. In reality, the boundary between the two types of research-at least in geography-are very blurred, but the fact is that applied research in 
EU projects is accompanied by many administrative tasks that turn researchers away from focused research work, but at the same they time generate new and generally useful skills and knowledge. Alongside a suitable project design and prudent organization, work on applied EU projects can be connected with basic research. There is a visible difference between the publications from the Seventh Framework Program and the Interreg projects. Many publications were created as part of the first, but these were mostly publications in prestigious foreign journals. The results of the Interreg projects are more frequently published in journals and publications of the participating institutions. Judging from the publications alone, EU projects-with the exception of the Seventh Framework Program and H2020-do not contribute to research excellence, but they do have a social impact and a positive influence on the profile of the institution.

The main challenges to employers are connected with planning work because business operation is an equation with many unknown variables. Even if a research group is successful in securing funding for a project, organizing the work is demanding. There is never just the right number of projects; there are always too many or too few of them.

The current atmosphere in society also affects the attitude to research and understanding it. The driving force behind research should be curiosity and creativity, whereas solving challenges is what is mostly financed. The effect of the greatest achievements, which are a result of curiosity and research enthusiasm, has only become evident with a delay. However, the EU operates in the framework of strategic cycles lasting several years, and it is justified to ask whether we know what the challenges will be after 2020. For the EU decision-makers, the social sciences and humanities, along with geography, seem to have limited use, even though the challenges of today's Europe are much more societal, social and cultural than technological. In Slovenia, the situation is even worse because research as a whole does not hold a suitable place in society, and a clear sense of anti-intellectualism is perceptible.

Obtaining project funding is a game with a low chance of winning, and the rewards are not always satisfying. The pre-award phase is exceptionally stressful because its success is linked to researchers' employment and social security, but the post-award phase is nearly as demanding, especially because of the complex administration. Balancing the rules from various levels is a great challenge, especially in decentralized programs, in which first-level control is carried out by Slovenian ministries. The content of projects often takes a second place to administrative and formal demands.

The life of researchers is pervaded by exceptional uncertainty. Applications are becoming increasingly demanding and frequent, and so time management is exceptionally difficult. It is not easy to balance time for research and publication-which has become much more intense due to the maxim of "publish or perish «-with applying for projects. Even research work alone is not concentrated and focused due to simultaneous work on multiple projects with different dynamics. It is good for individuals' and groups' project portfolios to vary, whereby basic research must be the core activity, offering support and material for applied research.

A multidisciplinary approach offers geographers many opportunities, but pitfalls as well because of the loss of focus. A narrow orientation, focus, and continuity are necessary for high-quality research work.

National funding remains a key source throughout Europe: only $8 \%$ of research in the EU is financed from the common budget. Member states are responsible for maintaining excellent basic research. Research is an expressly long-term activity, and it is only in a stable environment that it is possible to expect the creation of new knowledge. The contribution of European projects to developing the discipline and researchers' professional growth is clearly evident, but their contribution to developing research excellence is not self-evident. 